\title{
38- Osmanlı kültür coğrafyasında Batı Trakya ve Batı Trakyalı divan şairleri
}

\section{Amet MOLLA MEMET ${ }^{1}$}

APA: Molla Memet, A. (2021). Osmanlı kültür coğrafyasında Batı Trakya ve Batı Trakyalı divan şairleri. RumeliDE Dil ve Edebiyat Araştırmaları Dergisi, (25), 637-663. DOI: $10.29000 /$ rumelide.1036592.

\section{$\ddot{O} \mathbf{z}$}

Klasik Türk şiirinin gelişmesinde Rumelili şairler mühim bir yer tutar. İstanbul'un fethinden önce Bursa, Gelibolu, Edirne gibi şehirlerle beraber; Serez, Selanik, Yenice Vardar, Üsküp, Manastır, Filibe gibi Rumeli şehirleri de önemli kültür merkezleri olmuştur. Bu kültür coğrafyası arasında Batı Trakya da yer alır. Meriç ve Karasu nehirlerinin arasında kalan, Dimetoka ve Ferecik’i de içine alan Dedeağaç merkezli Evros, Gümülcine merkezli Rodop ve İskeçe illerinden oluşan Batı Trakya günümüzde Yunanistan sınırlarında bulunmaktadır. Batı Trakya Anadolu'nun Avrupa'ya açılan kapısıdır. Fethine 1359'da başlanıp 1373 yılında tamamlamış ve 1912'ye kadar beş buçuk asır Türk idaresinde kalmıştır. Fetihlerin batıya doğru ilerlemesi, daha büyük ve stratejik şehirlerin merkez edinilmesiyle ilk cazibesini kaybeden bölge bir geçiş güzergâhı hüviyetine bürünmüştür. Buna rağmen tekke ve medrese gibi iç dinamikleriyle canlı bir sosyokültürel hayata sahip olup; din, ilim, sanat, edebiyat ve siyaset alanlarında pek çok kişiyi yetiştirmiştir. İki bölümden oluşan bu makalenin ilk kısmında Dimetoka, Ferecik, Gümülcine ve İskeçe kasabalarının kısa tarihi, kültür ve edebiyat muhitlerinin oluşmasına tesir eden kişi ve kurumları zikredilmiştir. İkinci bölümde ise bu kasabaların fethinden kaybına kadar orada doğmuş şairler tanıtılmaya çalışılmıştır. Şairlerin tespiti için başta şair tezkireleri, ikincil biyografik kaynaklar, akademik çalışmalar ve yazma eser kütüphaneleri taranmıştır. Mukayeseli okumalar yapılarak şairlerin aileleri, eğitimleri, meslekleri, tasavvufi yönleri, seyahatleri gibi hayatlarına dair detaylar doğru ve muhtasar bir şekilde ortaya konulup hatalı bilgiler tashih edilmiştir. Ayrıca şiirlerinden örnek bölümler sunularak şairlik yönleri gösterilmiş ve eserlerinin vaziyeti hakkında bilgi verilerek yeni araştırmaların gerçekleşmesine imkân sağlanmıştır.

Anahtar kelimeler: Osmanlı Kültür Coğrafyası, Batı Trakya Şehirleri, Divan Şiiri, Batı Trakyalı Şairler

\section{Western Thrace in the Ottoman cultural geography and Western Thracian divan poets}

\begin{abstract}
Rumelian poets have an important place in the development of classical Turkish poetry. Before the conquest of Istanbul, together with cities such as Bursa, Gelibolu, and Edirne; Rumeli cities such as Serres, Thessaloniki, Giannitsa, Skopje, Manastir, and Plovdiv also became important cultural centers. Among this cultural geography is Western Thrace. Western Thrace which is located between the Maritsa and Nestos rivers, consisting of Alexandroupoli based Evros, which also includes Didymoteicho and Ferres, Komotini centered Rhodope and Xanthi, is located in the borders of Greece today. Western Thrace is the gateway of Anatolia to Europe. Its conquest started in 1359 and was completed in 1373, and remained under Turkish rule for five and a half centuries until 1912. The
\end{abstract}

Doktora, Bursa Uludağ Üniversitesi, Sosyal Bilimler Enstitüsü, İslam Tarihi ve Sanatları ABD, Türk İslam Edebiyatı Bilim Dalı (Bursa, Türkiye), ahmetmollamehmet@hotmail.com, ORCID ID: oooo-0002-2926-3184 [Araştırma makalesi, Makale kayıt tarihi: 18.11.2021-kabul tarihi: 20.12.2021; DOI: 10.2900o/rumelide.1036592]

Adres Address

RumeliDE Dil ve Edebiyat Araştrmaları Dergisi $\quad$ RumeliDE Journal of Language and Literature Studies Osmanağa Mahallesi, Mürver Çiçeği Sokak, No:14/8 Osmanağa Mahallesi, Mürver Çiçeği Sokak, No:14/8

Kadıköy - İSTANBUL / TÜRKIYE 34714 Kadıköy - ISTANBUL / TURKEY 34714 e-posta: editor@rumelide.com $\quad$ e-mail: editor@rumelide.com, tel: +90 $5057958124,+90216773$ o 616 phone: +90 505 7958124, +90 2167730616 
region, which lost its first attraction with the progress of the conquests to the west, larger and strategic cities, became a transit route. Despite this, it has a vibrant socio-cultural life with its internal dynamics such as tekke and madrasah, which have educated many people in the fields of religion, science, art, literature, and politics. In the first part of this two-part article, the brief history of the towns Didymoteicho, Ferres, Komotini, and Xanthi, the people, and institutions that influenced the formation of their cultural and literary circle are mentioned. In the second part, poets who were born there from the conquest of these towns until their loss was tried to be introduced. To identify the poets, primarily poet biographical sources, academic studies, and manuscript libraries were scanned. By making comparative readings, the details of the lives of the poets such as their families, education, professions, mystical aspects, travels were revealed correctly and concisely, and erroneous information was corrected. In addition, by presenting sample sections from their poems, their poetic aspects were shown, and by giving information about the state of their works, it was made possible to carry out new researches.

Keywords: Ottoman Cultural Geography, West Thracian Cities, Divan Poem, West Thracian Poets

\section{Giriş}

Osmanlı Devleti kuruluşundan kısa süre sonra batıya doğru akınlar düzenleyerek topraklarını genişletmeye başlamış ve XVII. asra değin devam eden fetihlerle Adriyatik’ten Hazar kıyllarına uzanan büyük bir ülke inşa edilmiştir. İstanbul'un fethine kadar Rumeli’nin önemli bölümünü hâkimiyeti altına alan Osmanlılar, iskân ve imar faaliyetleriyle bölgede uzun bir barış dönemini başlatmıştır. Ayrıca Fatih Sultan Mehmed’in (ö. 886/1481) resmî işlemlerde Türkçeden başka dil kullanılmaması hususundaki fermanı bölgede Türkçeyle beraber Türk kültür ve edebiyatının daha hızlı yayılmasını sağlamıştır (Çeltik, 2014: 32). Rumeli, kültür merkezi şehirleri, bu şehirlerde gelenek oluşturan şahısları, isimleri şehirleri ve asırları aşan münevverleriyle Osmanlı kültür coğrafyasının velûd bölgelerinden biri olmuş; bu geniş havzada yüzlerce siyasî, ilmî, dinî, edebî mahfil teşekkül etmiş ve Türk medeniyetinin gelişmesinde payı bulunan pek çok kişi yetişmiştir (İsen, 1997: 515-526).

Günümüze kadar Osmanlı devri ve sonrası Rumeli'deki Türk İslam kültürünü, bölgede beraber yaşayan farklı din ve milletlere müntesip insanların birbirlerinin dinî ve sosyal hayatlarına, dillerine ve edebiyatlarına tesirlerini inceleyen; Rumeli edebiyat dünyasını gerek kişi-eser bazlı gerekse şehirler üzerinden ele alan araştırmalar yapılmıştır. Mustafa İsen, Rıdvan Canım, Halil Çeltik gibi akademisyenlerin çalışmaları bu konuya örnek teşkil etmektedir. Fakat halen tahkik edilmesi gereken konular mevcuttur ve irdelenmeyi bekleyen yerlerden birisi de Osmanlı kültür coğrafyası arasında anılmaya değer Batı Trakya'dır. Batı Trakya özelinde gerçekleşen araştırmalar daha çok uluslararası ilişkiler, azınlık politikaları, tarih, tasavvuf, çağdaş edebiyat alanlarındadır ve bölgenin Osmanlı devri kültürel durumunu, sanat ve irfan mahfillerini, edebî birikimini ve şairlerini anlatan çalışmalara ihtiyaç duyulmaktadır. İki bölümden oluşan bu makalede Batı Trakya'daki Dimetoka, Ferecik, Gümülcine ve İskeçe kasabalarının kültür tarihimizdeki yeri, bu kasabalardaki edebî muhitler ve buralarda doğmuş şairler tespit edilerek tanıtılmıştır. İlk bölümde mezkûr Batı Trakya kasabalarının kısa tarihçesine, medrese, tekke gibi şehri ve şehir halkını dinî, sosyal ve kültürel anlamda besleyen kişi ve kurumlara yer verilmiştir. İkinci bölümde ise Osmanlı devrinde Batı Trakya'da doğmuş ve klasik tarzda şiirler nazmetmiş şairlerin muhtasar biyografileri yazılıp şiirlerinden örnek bir parça sunulmuştur. Makale bir metin neşri olmadığı için şiirler transkribe edilmemiş ve aruz kalıpları gösterilmemiştir. Şairlerin tespitinde tarama yöntemi kullanılarak; başta tezkireler, ikincil biyografik kaynaklar, tarih kitapları, akademik kitap, makale ve tezler, yazma eser kütüphaneleri incelenmiş ve ilgili şairler fişlenmiştir.

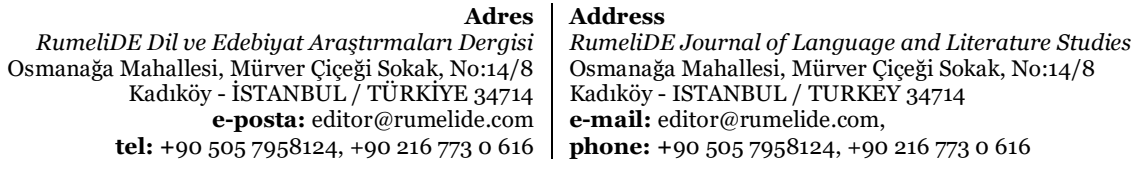


Hayatlarının yazımında bilgi veren kaynaklar arasında mukayeseli okumalar yapılarak doğru bir biyografi ortaya çıkartılmaya çalışılmış, hatalı bilgiler düzeltilmiş ve farklı malumat veren kaynaklar belirtilmiştir. Ayrıca tespit edilen şairlerin telif ettikleri eserler zikredilmiş, herhangi bir araştırmaya konu edilenler ile henüz incelenmeyip kütüphanelerde kayıtlı olanlar hakkında bilgi verilmiştir. Fakat ilgili kaynaklarda her şair için aynı derecede veri mevcut değildir. Önemli devlet memurluklarını, siyasî ve askerî görevleri ifa etmiş, farklı şehirler gezmiş, eserler vermiş, müderris ve şeyh gibi ilmî-tasavvufî payeleri olan şairlerin hayatlarına ait detaylar daha genişken; bulunduğu şehrin dışına çlkmamış ve mütevazı bir hayat benimsemiş şairlere dair bilgiler bazen sadece isminin ve doğum yerinin gösterilmesinden ibarettir. Bu kısımda bulunan şairlerin biyografileri şiirleri incelenerek oluşturulmaya çalışılmıştır.

\section{Batı Trakya}

Batı Trakya doğudan Meriç, batıdan Karasu nehirleri, kuzeyden Rodop dağları ve güneyden Ege denizi ile sınırlı, 8578 kilometrekarelik bir alanı kapsayan ve günümüz Yunanistan topraklarında bulunan bölgedir. Dimetoka ve Ferecik’i de içine alan Dedeağaç merkezli Evros ili, Gümülcine merkezli Rodop ili ve İskeçe illerinden oluşan Batı Trakya, Osmanlı'nın kuruluş devri sayılan zamanda fethedilmiştir (Halaçoğlu \& Eren, 1992: 5/144). 1357 yılında Meriç’in batı yakasına geçmeye başlayan Osmanlılar, 1373 senesinde Batı Trakya'nın tamamını hâkimiyeti altına almış ve Rumeli yarımadasında ilerleyişini sürdürmeye devam etmiştir (Sezgin, 2015: 3948). Beş buçuk asır süren Osmanlı idaresi 1912'de patlak veren Balkan Savaşlarıyla sona ermiş ve 1913 yllında imzalanan Bükreş Antlaşmasıyla Batı Trakya Bulgaristan'a verilmiştir. Rumeli'de kaybedilen toprakları geri almak ve Bulgarların Müslüman Türk halka uyguladığı zulümleri dindirmek üzere Enver Paşa’nın (ö. 1340/1922) emriyle Süleyman Askerî (ö. 1333/1915) ve Kuşçubaşı Eşref (ö. 1384/1964) önderliğinde oluşturulan milis birliklerle tekrar bölgeye giren Türk güçleri bugün Bulgaristan sınırlarında kalan Kırcaali, Mestanlı ve çevresini daha sonra da Gümülcine ve İskeçe'yi kurtarmıştır. Osmanlı Devletinin geri çekilmelerini istemesine rağmen bu birlik bölgede bağımsız bir devlet kurmaya soyunmuş ve 31 Ağustos 1913 yılında Garbî Trakya Hükümet-i Muvakkatesi’ni, 12 Eylül 1913’te de Garbî Trakya Hükümet-i Müstakilesi'ni ilan etmiş̧ir. Cumhuriyet yönetim sistemini benimseyen bu yeni ülke, cumhuriyet idare biçimini uygulayan ilk Türk devleti olma özelliğine de sahiptir (Baş, 2005: 29). Yeni hükümetin ilgası için büyük devletlerin Osmanlıya, Osmanlının da Batı Trakya'daki idarecilere baskısı sonucu Garbî Trakya Hükümet-i Müstakilesi 30 Ekim 1913'te feshedilmiş ve bölge Bulgarlara bırakılmıştır (Baş, 2005: 34). 24 Temmuz 1923 tarihinde imzalanan Lozan Barış Antlaşmasıyla Batı Trakya Yunanistan'a ve orada yaşayan Müslüman Türkler de mübadeleden hariç tutularak azınlık statüsünde, İstanbul'daki Rumların mukabilinde hâkim devletin himâyesine bırakılmıştır.

Batı Trakya Osmanlı’nın en uzun süre idaresinde tuttuğu Rumeli toprakları olmasına rağmen fetihlerin iç bölgelere ilerlemesinden dolayı bir geçiş güzergâhı konumunda kalmıştır. Buna karşın kendi içerisinde kültürel muhitler kurmuş ve Türk medeniyetine katkı sağlayan pek çok ismi yetiştirmiştir. İkinci bölümde zikredilen şairlerin hayatlarına bakıldığında bu kişilerin gelişmesinde ve tanınmasında Edirne’nin de büyük rolü olduğu görülecektir. İstidadı ve imkânı olan pek çok talebe, derviş ve şair Batı Trakya'daki muhitlerden istifade ettikten sonra Osmanlı ordularının aksine batıya değil doğu istikametine giderek Edirne'ye geçmiş ve tahsillerine devam etmiştir. Bu yönüyle Edirne, Rumeli ve özellikle Trakya bölgesinin ilim ve kültür başkenti olmuştur.

Makalenin devamında Batı Trakyalı şairlerin doğup yetiştikleri yerleri görmek ve onları tanımaya bir zemin oluşturmak adına Dimetoka, Ferecik, Gümülcine ve İskeçe kasabalarının ilk kuruluş, fetih ve

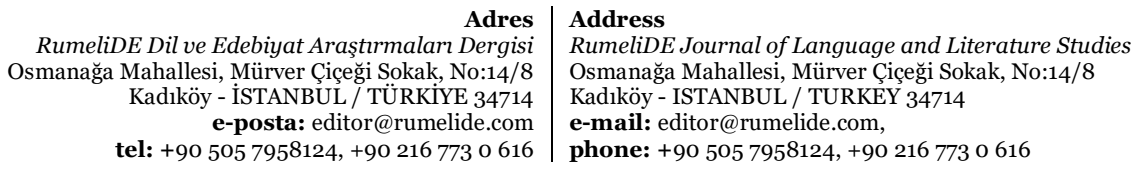


elden çıkışına kadarki tarihî serencamı, dinî, ilmî ve edebî muhitlerini oluşturan unsurları muhtasar bir şekilde ele alınmıştır.

\subsection{Dimetoka}

Dimetoka günümüzde Evros iline bağll, Edirne’nin $40 \mathrm{~km}$ güneyinde ve Yunanistan sinırlarında bulunan bir kasabadır. Kızıl Deliçay’ın çevrelediği kayalık plato ve aşağıya doğru uzanan düzlük üzerinde yer alan Dimetoka ilk olarak İmparator Trajanos (ö. 117) tarafından Plotinopolis adıyla kurulmuştur. Barbar istilaları tarafından tahrip olan şehir bilahare İmparator İustinianos (ö. 565) eliyle tekrar inşa edilmiş ve çifte surlarla çevrildiği için “çift duvarlı” anlamına gelen Didymoteihon adını almıştır. Osmanlı devrinde ismi değiştirilmeyen kasaba Türkçe söyleyişe uygun olarak Dimetoka olarak kullanılmıştır (Kiel, 1994: 9/305). Türk hâkimiyetine kadar sürekli bir istikrarın var olmadığı Dimetoka bazen Bizans'ın bazen Bulgar krallğının idaresine geçmiştir. 1359 yllında Sultan I. Murad'ın (ö. 791/1389) kumandanı Hacı İlbey (ö. 766/1365’ten sonra) tarafından fethedilen kasaba Osmanlıların Rumeli'ye geçişlerinin, yerleşmelerinin ve ufuk yönlerinin göstergesi olmuştur. Bunun delili de 1361'de Edirne'nin fethedilmesine rağmen 1367 yllına kadar uzayan şehrin tamir ve tertibi müddetince Sultan I. Murad'ın Dimetoka'yı Osmanlı Devletinin başkenti yapmasıdır. Bu zaman içerisinde kasabaya saray, imaret ve pek çok eser kazandıran Sultan I. Murad Dimetoka'nın "Dârü's-saltanat" diye anılmasını sağlamıştır (Tuğlacı, 1985: 338). Bu Dimetoka'nın ikinci defa payitaht oluşudur. 1341 senesinde İoannes Kantakuzenos da burada imparatorluğunu ilan etmiş ve Konstantinopolis'e geçene kadar Dimetoka'yı başkent edinmiştir (Bozcu, 2017: 58). Dimetoka'nın üçüncü defa başkent oluşu ise Fetret devrine rastlar. Rumeli'yi ele geçiren Musa Çelebi (ö. 816/1413) Dimetoka'yı hükümet merkezi yapmış ve Çelebi Mehmed (ö. 824/1421) idarede dirliği sağlayana kadar burada bulunmuştur (Tuğlacı, 1985: 339). 1912 senesinde patlak veren Balkan Savaşlarına kadar 553 yıl Türk hâkimiyetinde kalan Dimetoka bu tarihten sonra imzalanan farklı antlaşmalarla önce Bulgaristan'a sonra da Yunanistan'a verilmiştir.

Önemli devlet adamlarının sayfiye ve sürgün yeri olmasından dolayı mimarî ve kültürel anlamda canlı bir hayat yaşanan kasabada farklı kişilerce pek çok eser inşa edilmiştir. Bunlardan en önemlisi Yıldırım Bayezid'in (ö. 805/1403) başlattığı ve oğlu Çelebi Mehmed'in tamamladığ Çelebi Sultan Mehmed Camii'dir. Rumeli'nin en büyük camii olma özelliğine sahip mabet Bursa Yeşil Cami'nin de mimarı olan Hacı İvaz Paşa (ö. 831/1428) tarafından inşa edilmiştir (Eyice, 1993: 8/262). Cami günümüzde maalesef diğer eserler gibi atıl haldedir ayrıca 2017 yılında çıan yangında büyük hasar görmüş, bir örneği daha bulunmayan kırlangıç kubbeli çatısı tamamen yanmıştır.

Payitahtın önce Edirne sonra İstanbul'a taşınmasıyla ilk cazibesini kaybeden Dimetoka, Edirne'nin gölgesinde bir kaza merkezi olarak varlığını sürdürmekle beraber iç dinamikleriyle canlılığını korumuştur. Şucaeddin İlyas Rûmî (ö. 920/1514), Molla Lutfî (ö. 900/1495) ve Molla İzârî (ö. 901/1496) gibi müderrisler; Abdülvâsî Çelebi (ö. 945/1538) ve Lütfi Paşa (ö. 970/1563) gibi devlet adamlarının etrafında oluşan edebî muhitlerin yanında Seyyid Ali Sultan Tekkesi Dimetoka ve çevresini irfanî ve kültürel anlamda besleyen merkez olmuştur. Seyyid Ali Sultan (ö. 815/1412'den sonra) Kalenderî neşveye sahip bir derviş olarak Türkistan'dan Anadolu'ya gelmiş ve Elmalı'daki Abdal Musa Dergâhı'nda bir müddet bulunduktan sonra dervişleriyle beraber Osmanlı ordusuna katılarak Rumeli fetihlerinde önemli yararlılıklar göstermiştir. Dimetoka yakınlarında günümüzde Ruşenler köyü olarak bilinen yerde dergâhını kuran Seyyid Ali Sultan, Yıldırım Bayezid ve oğlu Musa Çelebi tarafından sunulan pek çok ikramlarla desteklenmiş. Bektâşilliğin mühim merkezlerinden kabul edilen Seyyid Ali Sultan Dergâhı İslam'ın ve Bektâşîliğin Rumeli'de yayılmasında büyük bir görev ifa etmiştir (Şahin, 2009: 37/48). Yine Bektâş̂liğin ikinci piri kabul edilen ve tarikatı sistemleştiren Balım Sultan (ö. 922/1516) bu dergâhta 
yetişip Sultan II. Bayezid'in (ö. 918/1512) emriyle Hacı Bektaş’taki âsitâneye postnişin olarak tayin edilmiştir (Ocak, 1992: 5/17).

Medrese ve tekke ekollerinin birlikte muhit oluşturdukları Dimetoka kabasından beş asrı aşkın zaman içerinde pek çok devlet adamı, âlim, ârif ve şair yetişmiştir. Silahdâr Seyyid Mehmed Paşa (ö. 1171/1758), müderris ve kadılık vazifelerinde bulunmuş Şucaeddin İlyas Rûmî (ö. 920/1514) ve Molla Lutfî (ö. 900/1495) ile ikinci bölümde zikredilen şairler Dimetoka’nın kültür havzasından beslenmiş kişilerden bazılarıdır.

\subsection{Ferecik}

Ferecik günümüzde Evros iline bağlı, İpsala'nın hemen karşısında, Türkiye hududuna 20 km mesafede ve Yunanistan sinırlarında bulunan bir kasabadır. 1152 yılında Bizans İmparatoru II. İoannes'in (ö. 538/1143) kardeşi İsak Komnenos'un (ö. 547/1152) kurduğu Panagia Kosmosoteire Manastırı Vakfı etrafında oluşan kasaba, civarının bataklık ve göllerle çevrili olmasından dolayı Yunanca "bataklık" anlamına gelen "Vera" adıyla anılmıştır. Türk hâkimiyetine geçince de bu isim Türkçe söyleyişe uyarlanarak "Fire, Fere, Firecik, Ferecik" diye kullanılmıştır (Kiel, 1995: 12/371). Ferecik'in Osmanlılar tarafından fethi konusunda farklı tarihler ileri sürülmekle beraber 1357 yılı genel kabul görmüştür. Orhan Gazi'nin (ö. 763/1362) oğlu Süleyman Paşa (ö. 758/1357) tarafından fethedilen kasaba Rumeli topraklarında Orhan Gazi adına ilk hutbenin okunduğu yer olma özelliğine de sahiptir. Süleyman Paşa şehri ele geçirince Panagia Kosmosoteire Manastırı'nı camiye tebdil etmiş ve Rumeli'deki ilk Cuma namazı burada kılınmıştır (Öztürk, 1989: 135). 1912'de başlayan Balkan Savaşlarına kadar 555 yıl Osmanlı idaresinde kalan kasaba bu tarihten sonra imzalanan farklı antlaşmalarla önce Bulgaristan’a sonra da Yunanistan'a verilmiştir.

Ferecik beş asrı aşkın zaman Türk, Rum ve Bulgar halkıyla 2000-300o nüfuslu bir kaza merkezi olmanın ötesine gidememesine rağmen ilklerin yaşandığı ve tasavvufî kültürün güçlü hissedildiği bir kasabadır. Bahsedildiği gibi Osmanlı ilk Cuma namazını burada kılmış ve Osmanlı sultanı adına ilk hutbe burada okunmuştur. Yine Zeyniyye tarikatı ilk defa Ferecikli Şeyh Sinan Efendi (ö. 890/1486) vasıtasıyla Rumeli'ye girmiştir (Mecdî, 1989: 1/258). Şeyh Sinan Efendi'den sonra oğlu Şeyh Ali Efendi (ö. 957/1550) irşat vazifeni devralmış ve bölgede ilmî, irfanî ve edebî hayatın sürdürülmesine katkı sağlamıştır (Bâdî, 2014: 3/2214). Bu dergâhın yetiştirdiği en mühim isim manzum Osmanlı tarihi nazmetmiş şair Hadîdî'dir (ö. XVI. yy.). Ferecik Halvetî Dergâhı da Trakya ve çevresinde etkili kurumlardan birisidir. Ferecikli Halvetî şeyhi Şaban Efendi'de sülûkunu tamamlayıp İstanbul Akbıyk Sultan Tekkesi'ne postnişin olan ve "Sakızlı Şeyh" lakabıyla maruf Çaresiz İlyas Efendi (ö. 1118/1706) gibi pek çok sufi şairi yetiştiren Şeyh Çarhacı Ahmed Efendi (ö. 1080/1669) burada neşvünema bulmuş kişilerdendir (Ergün, Tarihsiz: 3/1112; Tanman, 1989: 2/222). Zeynîliğin ve Halvetîliğin yanında kasabanın sosyokültürel ve dinî hayatını besleyen, edebî muhit oluşturan dergâh ve zaviyeleri arasında; Âşıklar Zaviyesi olarak da bilinen Nefes Baba Bektâşî Zaviyesi, Ahi Turhan Zaviyesi ve Ahi Horasan Zaviyesi bulunmaktadır (Bıçakçı, 2003: 82).

\subsection{Gümülcine}

Gümülcine günümüzde Rodop iline bağll, Türkiye hududuna $98 \mathrm{~km}$ mesafede, Batı Trakya'nın merkezinde ve Yunanistan sinırlarında bir kasabadır. Gümülcine'nin temelleri ilk defa Roma devrinde atılmıştır. Roma İmparatoru Theodosios (ö. 395) günümüz Gümülcine'sinin yakınlarında bulunan fakat barbar saldırıları ile harap olmuş Mosinopoli kasabasında mukim insanların daha güvende yaşamaları

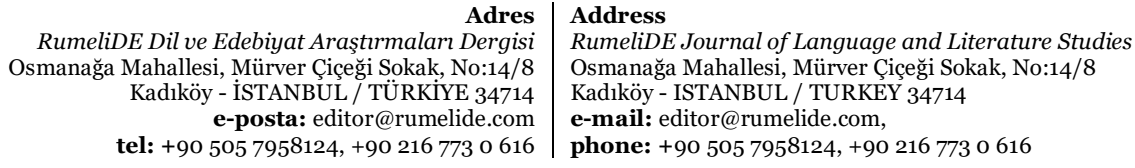


için 380-385 yllarında Koumoutsina adıyla bir kale inşa etmiş ve şehir ortaya çıkmıştır (Kiel, 1996: 14/268). XIV. asra kadar Bizans idaresinde bulunan şehre ilk Türk taarruzları 1344 yllında Aydınoğlu Umur Bey (ö. 748/1348) tarafından gerçekleştirilmesine rağmen kalıcı bir hâkimiyet sağlanamamıştır. $\mathrm{Bu}$ tarihten itibaren "Gümülcine" adıyla anılmaya başlanan şehir Gazi Evrenos Bey (ö. 820/1417) önderliğindeki akıncı birlikleriyle Çirmen Savaşından önce, 1361-1371 tarihleri arasında fethedilmiştir (Eren \& Türe, 2017: 9). 1371-1383 yıllarında batıya doğru düzenlenecek harekâtlarda Gümülcine'yi uç merkezi olarak kullanan Gazi Evrenos Bey şehrin İslamlaşması ve Türk kimliğine kavuşmasında mühim rol oynamış; başta Anadolu'dan getirilen Müslüman Türklerin iskânı, inşa ettirdiği imaret, hamam, medrese ve camiiyle Gümülcine'nin hem demografik hem de mimarî anlamda şekillenmesinde öncü olmuştur (Kılıç, 2012: 259). 1912 ylına kadar Osmanlı idaresinde kalan Gümülcine bu süre içerisinde siyasî konjonktür icabı liva, vilayet, nahiye, kaza gibi değişen statülere getirilmiştir. En son vaziyeti ise Edirne vilayetine bağlı bir sancak merkezi olmasıdır (Parlak, 2013: 87). 1912'de başlayan Balkan Savaşlarına kadar kesintisiz $55^{0}$ yıl Osmanlı idaresinde kalan kasaba bu tarihten sonra imzalanan farklı antlaşmalarla önce Bulgaristan'a sonra da Yunanistan'a verilmiştir.

Gümülcine on yll süren uç merkezliğinden sonra akınların batıya doğru ilerlemesinden, merkezî birimlerin daha büyük ve stratejik şehirlere taşınmasından dolayı ilk zamanlardaki cazibesini kaybetmiş ve geçiş güzergâhında bulunan bir kasaba hüviyetine bürünmüştür. Buna rağmen kendi içinde ilim, irfan ve edebiyat mahfilleri meydana getirmeyi başarmıştır. Gazi Evrenos Bey'in şehre prototip olarak sunduğu imareti daha sonra kurulacak vakıflara, medreselere ve tekkelere mihmandarlık ederek şehrin sosyokültürel yapısına, dinî, ilmî ve edebî kimliğine şekil vermiştir. Bu vakıflardan en mühimi Defterdâr Ekmekçizâde Ahmed Efendi Vakfi'dır. Edirneli Ekmekçizâde Ahmed Paşa (ö. 1027/1618) tarafından kurulan bu vakıf günümüzde de cazibesini koruyan Yeni Cami’i ve pek çok münevverin yetişmesini sağlayan Yeni Cami Medresesi’ni inşa etmiş ayrıca mektep, hamam, kütüphane ve imaret gibi şubeleriyle şehir halkına hizmet etmiş̧ir (Parlak, 2018: 26). Şehrin ilim ayağını oluşturan diğer medreseler ise Kır Mahalle Karaca Mehmed Medresesi, Kayalı Medresesi, Sohtalar Medresesi, Tekke Medresesi ve Yunus Bey Medresesi'dir (Eren \& Türe, 2017: 17). Günümüzde sadece Kayalı Medresesi "Medrese-i Hayriye" adıyla faal haldedir (Eren, 2001: 57). Ayrıca şehrin dinî ve kültürel hayatına canlılık katan tekke ve ârif kişileri arasında Post Pûş Baba Tekkesi, Gümülcine Uşşâkî Dergâhı ve bu dergâhın şeyhlerinden Halil Efendi, Abdülkerim Efendi, Osman Sıdkî Efendi (Bâdî, 2014: 3/2246), Yenice Mahalle'de kendi ismiyle anılan mescitte hizmet veren Süpüren Dede, Aşçı Hasan Baba, Serdar Mahalle'de mukim Rufâî şeyhi Saçlı Ahmed Efendi ve Kayseri'den gelip Gümülcine’ye yerleşen Kadirî şeyhi Süleyman Efendi bulunmaktadır (Eren \& Türe, 2017: 19).

Tasavvufî kişi ve kurumlarının çeşitliliğine ve çokluğuna rağmen diğer Batı Trakya kasabalarına kıyasla Gümülcine'de medrese ekolü güçlüdür. Gümülcineli müelliflerin yetiştikleri yerlere bakıldığında bu vaziyet alenen görülecektir ki; Bursa, Mekke ve Medine'de kadılık yapmış Abdullah Efendi (ö. 1098/1687), kelam alanında eserleri bulunan Müderris Muhammed b. Ahmed Gümülcinevî (ö. 1203/1788), Seyyid Mehmed Efendi (ö. 1203/1788), Kır Mahalle Medresesi müderrisi Mehmed Hilmi Efendi (ö. 1336/1918), şair Mehmed Esad Efendi (ö. 1376/1957) Gümülcine medreselerinde tahsil görmüş, Osmanlı coğrafyasının farklı yerlerinde vazifede bulunmuş ve eser vermiş kişilerdendir.

\section{4. İskeçe}

İskeçe günümüzde Trakya'nın batı ucunda, Karasu nehrine yakın, Gümülcine’ye $47 \mathrm{~km}$, Türkiye hududuna $193 \mathrm{~km}$ mesafede, Yunanistan sınırlarında bulunan ve İskeçe ilinin merkezi de olan bir yerleşim yeridir. Şehrin tarihi antik çağlara kadar götürülmekle birlikte, Bizans İmparatoru II.

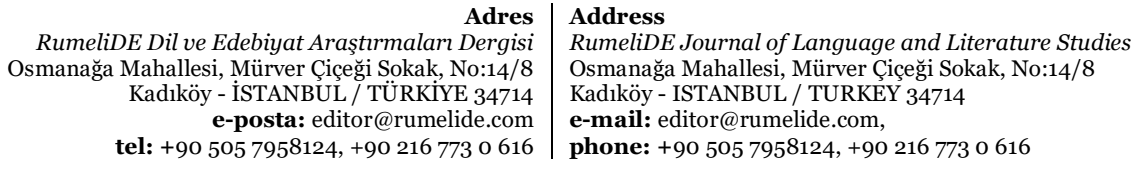


Andronikos (ö. 732/1332) şehri başpiskoposluk merkezi konumuna getirerek gün yüzüne çıkarmış ve tanınırlığını arttırmıştır (Kiel, 2000: 22/553). 1373 yılında Gazi Evrenos Bey tarafından fethedilen İskeçe küçük ve dağllk bir konumda bulunmasından dolayı ilk zamanlar iskân için tercih edilmemiştir. İskeçe yerine Karasu nehrine daha yakın ve verimli arazileriyle düz bir ovada kurulmuş Yenice Karasu köyüne geçen ve Anadolu'dan getirdiği Müslüman Türk yörükleri de buraya yerleştiren Evrenos Bey Yenice’yi köy hüviyetinden çıararak büyük bir Türk kasabasına tebdil etmiştir. XIX. asra kadar Yenice Karasu'ya bağlı olan İskeçe bu tarihten sonra idare merkezi yapılmıştır (Ağanoğlu, Bayram, \& Yıldıztaş, 2009: 17). İdareye kavuşmasından sonra nüfusunda artma ve imar faaliyetlerinde hızlanma görülen şehir 1912 senesinde başlayan Balkan Savaşlarından sonra 539 yıl kaldığı Osmanlı hâkimiyetinden çımış ve diğer Batı Trakya şehirleri gibi önce Bulgaristan sonra da Yunanistan'ın idaresine bırakılmıştır.

XIX. yüzylla değin halkının ekserisi Hristiyanlardan oluşan İskeçe bu tarihe kadar Türk İslam geleneğine dair gerek imar, gerek kültür, gerekse yazım sahalarında az sayıda faaliyete sahne olmuştur. İdarenin İskeçe merkezine taşınmasından sonra artan nüfusla beraber İslamî yaşantının sürdürülebilmesi için çalışmalar hızlanmıştır. Mevcut Debbağhane ve Çınar camileri tamir edilmiş, Aşağı Mahalle Camii ve şehrin sembollerinden saat kulesi bu tarihten sonra inşa edilmiştir (Bıçakçı, 2003: 190). Tasavvufî hayatında da hareketlik gözlemlenen İskeçe'de iki Bektâşî şeyhi olan Hasîb Baba ve İbrahim Baba 1883 yılında İskeçe Bektâşî Dergâhı'nı kurmuş ve bu dergâhın kitabesini de son dönemin meşhur Bektâşî şeyhlerinden Mehmed Ali Hilmi Dedebaba (ö. 1324/1907) yazmıştır (Bıçakçı, 2003: 198). Yine 1880 yılında Aşağı Mahalle'de Halvetîliğin Şabaniye koluna ait Ahmed Baba Dergâhı ve aynı mahallede fakat ne zaman inşa edildiği bilinmeyen Kadirî Dergâhı kurulmuştur (Bâdî, 2014: 3/2251). Beylerbeyi Kâmilî Halil Paşa (ö. 1309/1891), Eyüp Mollası Müderris Halil İbrahim Efendi (ö. 1251/1836) ve diğer İskeçeli şairlerin çoğu İskeçe'nin merkez hüviyetine kavuşmasından sonra yetişmişlerdir (Bâdî, 2014: 3/2252).

\section{Batı Trakyalı şairler}

\subsection{Dimetoka doğumlu şairler}

\section{Fehîm}

Fehîm Efendi Dimetoka'da dünyaya gelmiştir. Hakkında geniş bilgi bulunmayan şair, Edirne gümrük dairesinde başkâtip olarak görev almış ve 1286/1869 yllında vefat etmiştir. Herhangi bir esere sahip olduğu bilinmeyen Fehîm Efendi'nin Riyâz-ı Belde-i Edirne'de bir gazeli mevcuttur (Bâdî, 2014: 3/2003).

Kâmetindir nahl-i ser-keş serv-i bâlâdan garaz

Ebruvânın "kâbe kavseyni ev ednâ"dan garaz

Gülşen-i hüsnünde uşşâkın şehâ olsun hezâr

Ârız-ı âlin degil mi verd-i hamrâdan garaz

Almayam dest u dile hiç bezm-i mey peymânesin

Bûs-i la'lindir senin câm-ı musaffâdan garaz

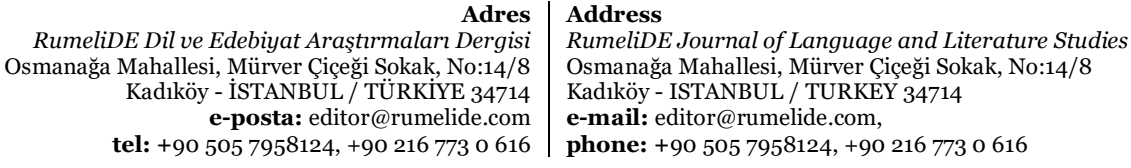

Address

RumeliDE Journal of Language and Literature Studies

Osmanağa Mahallesi, Mürver Çiçeği Sokak, No:14/8

Kadıköy - ISTANBUL / TURKEY 34714

e-mail: editor@rumelide.com,

phone: +90 $5057958124,+902167730616$ 
Fikre alır dehr-i dûnı mest u medhûş olmayan

Olmadır mestlik müdâm u terk-i dünyâdan garaz

Söyle Fehmî âşık-ı dil-hasteler bulsun hayât

Nutk-i pâkindir senin ancak Mesîhâ'dan garaz (Bâdî, 2014: 3/2003)

\section{Hayâlî}

Abdülvehhab Hayâlî Çelebi Dimetoka'da doğmuştur. Babası Molla Abdülkerim Efendi'dir (ö. 895/1489). Devrinin önde gelen ulemasından dersler alıp tahsilini tamamlayan Hayâlî, İstanbul Kalenderhâne Medresesi ve Edirne'deki Camialtı Medresesi'nde müderrislik yapmıştır. Bilahare kadılı̆̆a geçen Hayâlî Çelebi; Manisa, Selanik ve Tire kadılıklarında bulunmuştur. Şehzade I. Selim’in (ö. 926/1520) sancak beyliği yaptı̆̆ı Trabzon'da şehzadenin musahibi olan Hayalî, I. Selim’in tahta geçmesiyle baş defterdârlığa tayin edilmiştir. 1515 yllında Amasya'da yeniçeriler arasında çlkan tartışmadan mesul tutulup azledilince eski mesleğine dönerek İzmir kadılığına başlamıştır. 930/1524 yılında İzmir kadısı iken vefat eden Abdülvehhab Hayâlî Çelebi Edirne'de babasının yaptırdığı mektebin haziresine defnedilmiştir (Bâdî, 2014: 2/1325; Beyânî, 1997: 89; Çelebi, 2010: 3/1538; İpekten, vd., 1988: 196; Kınalızâde, 2017: 342; Latîfî, 2000: 252; Mecdî, 1989: 1/333; Riyâzî, 2017: 145; Sehî, 1998: 81; Süreyya, 1996: 2/656; Tevfik, 2017: 308; Tuman, 2001: 1/260).

Meşhur Hayâlî Bey'den (ö. 965/1557) ayırmak için Hayâlî-i Evvel ve Hayâlî-i Kadîm olarak anılan şair; hayal gücü kuvvetli, nazmı rengin, âşıkane şiirler söyleyen ve devrin önemli şuarâsından görülmüştür. Tezkirelerde "Leyla vü Mecnûn" mesnevisinden bahsedilmesine rağmen herhangi bir kaydına ulaşılamamıştır. Edirneli Nazmî̀nin mecmuasında 12 (Nazmî, 2017: 45), Pervâne Bey mecmuasında 1 gazeli (Pervâne, 2017: 2261) ve Peşteli Hisâlî mecmuasında 2 beyti bulunmaktadır (Kalyon, 2011: 1407). Ayrıca bu şiirler pek çok şair tarafından tanzir edilmiştir.

Hışm ile ol kâfir-i bed-kîş kirban baglanur

Vâlih ü ser-geşte dillerde kara kan baglanur

Gam degildür müdde'î men itse kûyundan beni

Resmdür çün hâr ile râh-ı gülistân baglanur

Bagladum dilde hayâl-i la'lüni agyâr içün

Dîvden korkan belî mühr-i Süleymân baglanur

Her seher sûz-ı derûnumdan yanar kandîl-i arş

Her gice dûd-ı dilümden râh-ı Keyvân baglanur

Ey Hayâlî şekkerîn güftâruna irmez senün

Âlem içre gerçi ma'nâlar firâvân baglanur (Nazmî, 2017: 478)

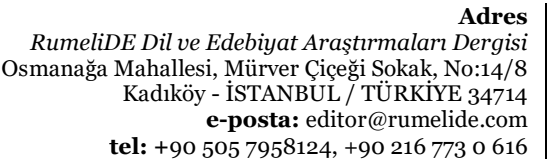

RumeliDE Dil ve Edebiyat Araştırmaları Dergisi Kadık̈y - ISTANBUL/TÜRKYY tel: +90 505 7958124, +90 2167730616
Address

RumeliDE Journal of Language and Literature Studies

Osmanağa Mahallesi, Mürver Çiçeği Sokak, No:14/8

Kadıköy - ISTANBUL / TURKEY 34714

e-mail: editor@rumelide.com,

phone: +90 $5057958124,+902167730616$ 


\section{Remzî}

Nazif Remzî Efendi Dimetoka doğumludur. İlk tahsiline memleketinde başlayıp daha sonra Edirne İdâdî Mektebi'nde eğitim hayatına devam eden Remzî, henüz genç bir öğrenci iken 1296/1878 yılında vefat etmiştir. Remzînnin herhangi bir esere sahip olduğu bilinmezken Bâdî Efendi’nin Riyâz-ı Belde-i Edirne'sinde şiirine örnek olarak bir gazeli bulunmaktadır (Bâdî, 2014: 3/2002).

Safha-i târem-i mînâda görünce titrer

Mâh-ı garrâ kaşını rûyını şems-i enver

Kesret-i hışm u hasetle tadın gâib eder

Kand-i nâb-ı lebinin vasfin işitse sükker

Câm-ı rengîn lebin bezme gelip ihsân et

Durmasın tizce içilsin ki durursa kükrer

Kal'a-i mülk-i cemâline metânet ver kim

Etmesin leşker-i hattın anı yagma dil-ber

Remzî ehl-i hünerin afvın der-hâtır edip

Gazel-i Bâdî Efendi'ye nazîre söyler (Bâdî, 2014: 3/2002)

\section{Rızâyî}

Kassabzâde Abdülkerim Rızâyî Efendi Dimetoka'da dünyaya gelmiştir. Ailesi aslen Bursalı olup babası Dimetoka kadısı Ali Çelebi'dir. Ailesinin Bursa ile özdeşleşmesinden dolayı Ahdî ve Ahmed Bâdî Efendi hariç adının bulunduğu tezkireler onu Bursalı olarak tanıtmaktadır. Laubali mizaçlı olduğundan Deli Kerim lakabıyla anılan şair, devrin ileri gelen âlimlerinden özel dersler alarak tahsilini tamamlamıştır. Müderrislik vazifesiyle Dimetoka, Edirne, Çorlu, İstanbul ve Bursa'da görev yapan Rızâyî bilahare Kudüs kadılı̆̆ına atanmıştır. 985/1577 yılında vazifesi başında vefat eden Rızâyî Kudüs'te medfundur (Ahdî, 2018: 75; Atâî, 1989: 2/245; Bâdî, 2014: 3/2002; Beyânî, 1997: 102; Çelebi, 2010: 3/1370; İpekten, vd., 1988: 388; Kınalızâde, 2017: 387; Riyâzî, 2017: 162; Süreyya, 1996: 5/1392; Tuman, 2001: 1/355).

Türkçe, Arapça ve Farsça dillerinde şiir yazmaya muktedir, muamma söylemede usta bir şair olan Rızâyî'nin herhangi bir esere sahip olduğu bilinmezken, "Mecmu'atü'l-Letâif ve Sandukatü'l-Maârif" adlı mecmuada 15 gazeli (Gürbüz, 2018: 1013), Kabîlînnin mecmuasında 37 (Kabîlî, 2018: 1173) ve Peşteli Hisâlı̂nnin mecmuasında da 3 beyti bulunmaktadır (Kalyon, 2011: 1416).

Sanma sûfî eşk-i sürh ile rûh-i zerd isterin

Işk dirler adına bir bî-devâ derd isterin

Âteş-i işkunla budur yakdugum dâg üzre dâg

Ey tabîb-i cân u dil derd üstine derd isterin

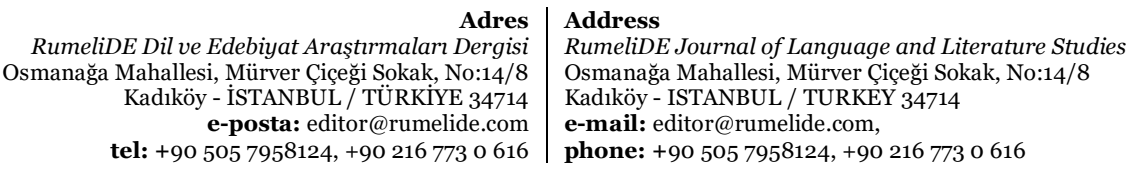


Dâ'irem devr itmesün kec-rev olan pergâr-veş

Sath-ı dehre hat çeküp dil noktasın ferd isterin

Mihr-i âlem-sûz gibi bir harâretdür murâd

Sanma vâ’iz âh-ı germ ile dem-i serd isterin

Bîve-i dünyâ-yı dûnı boşayup erlik ide

Ey Rızâyî bir kuşagına tolu merd isterin (Gürbüz, 2018: 697)

\section{Sâdık Abdal}

Sâdık Abdal XIV. asrın ikinci yarısında Dimetoka'da doğmuştur. Hayatı hakkında geniş bilgi bulunmayan şair 13-14 yaşlarında Seyyid Ali Sultan Dergâhı'ndaki dervişlerle tanışmış ve 22 yaşında da Seyyid Ali Sultan’a (ö. 815/1412'den sonra) intisap etmiştir. Ömrünü dergâha hizmetle geçiren Sâdık Abdal’ın ölüm tarihi bilinmemektedir. Fakat divanında Abdal Musa (ö. XV. yy.), Kaygusuz Abdal (ö. 848/1444), Otman Baba (ö. 883/1478) gibi yaşadığı dönemin Bektâş̂̂ ulularının anılıp; Balım Sultan (ö. 922/1516), Yemînî (ö. XVI. yy.), Demir Baba (ö. XV. yy.) gibi önemli isimlerin bulunmayışı onun XV. asrın ilk yarısında vefat ettiğine delil olarak gösterilebilir (Ergün, 1955: 207; Gümüşoğlu, 2012: 1-25; Kaya, 2016: 259; Tan, 2014).

Sâdık Abdal'ın bağlı bulunduğu yolun azizlerine yazdığı methiyeler, nasihatler ve tasavvufî remizlerle bezeli, aruz ve hece vezinlerini kullandığı mürettep Divan'ı mevcuttur (Abdal, 2019). Bu divan XV. yüzyl Bektâşî kültürüne ve Seyyid Ali Sultan Dergâhı'ndaki yaşantıya dair izler barındırmakta ve ilk devir Bektâşîliğinin tanınmasına imkân vermektedir (Soileu, 2014: 79-88).

Dediler ism-i bülendine anın Seyyid Ali

Dahî mahlâsına Kızıl Deli denildi güzîn

Akribâdır ana Sultan Hacı Bektâş-ı Velî

Ya’ni evlâd-ı Ali asl-ı şerîf ile saîd

Çâkeri Sâdık’a ol şâh-ı velî kıldı nazar

Ber-murâd etti beni kılmadı mahrûm-ı ümîd (Ergün, 1955: 208)

\section{Silahdâr Seyyid Mehmed}

Silahdâr Seyyid Mehmed Paşa Dimetoka'da doğmuştur. İlk tahsilini memleketinde tamamlayıp İstanbul'a giden Seyyid Mehmed, Enderun'a dâhil olarak iyi bir eğitim almıştır. Tedricen memuriyette yükselmeye başlayan şair, 1733 yılında silahdâr-ı şehriyârî, 1736'da ise sadrazam olmuştur. 1736'da katıldığı Kırım seferindeki başarısızlığından dolayı 1737 yılında görevinden azledilip Eğriboz adasında yaşamaya mahkûm edilen Seyyid Mehmed Paşa bilahare affedilip; 1742'de Eğriboz, 1745'te Özi, 1746'da Hanya, 1747 'de Belgrat, 1748 'de İnebahtı, 1751'de Selanik ve Cidde muhafızlıklarına atanmıştır. 1170/1757'de hac farizasını yerine getirmek üzere bulunduğu Mekke'de vefat eden Seyyid Mehmed Paşa orada defnedilmiştir (Köksal, 2015; Sami, 1316/1898: 6/4200; Süreyya, 1996: 4/1070; Tuman, 2001: 2/921).

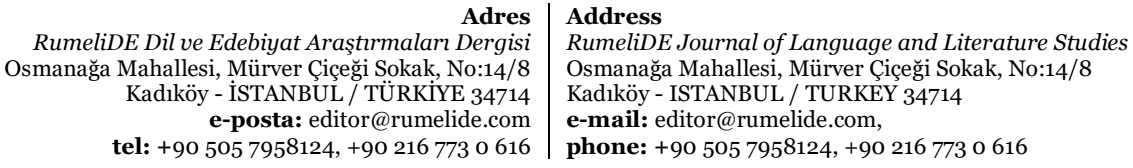


Siyasî ve askerî tecrübesinin yanında güçlü bir ilmî birikime de sahip olan Seyyid Mehmed Paşa'nın herhangi bir esere sahip olduğu bilinmezken Tuhfe-i Nâilı’'de bir beyti bulunmaktadır.

Ferzend-i Sitanbul'am ferzend-i Sitanbul

Fazlıyla ider feyze Kâdir bizi mevsûl (Tuman, 2001: 2/921)

\section{Vâsî}

Abdülvâsî Çelebi Dimetoka'da dünyaya gelmiştir. Babası Dimetoka'nın bilinen kişilerinden Hayreddin Hızır Bey'dir. Tahsilini memleketinde tamamlayan Vâsî, Şücaeddin İlyas Rûmî (ö. 920/1514), Molla Lutfî (ö. 900/1495) ve Molla İzârî (ö. 901/1496) gibi devrin önde gelen ulemasının hizmetinde bulunmuştur. II. Bayezid (ö. 918/1512) döneminde patlak veren Aşere-i Muhabbese (on habis insan) olayında başta hizmetinde bulunduğu Molla Lutfî olmak üzere pek çok kişiyle beraber zındıklıkla suçlanan Vâsî, takibattan kurtulmak için İran'a kaçmıştır (Erünsal, 2004: 127-157). Yavuz Sultan Selim’in (ö. 926/1520) tahta geçmesinden sonra Osmanlı topraklarına dönen Vâsî Çelebi, sırasıyla Edirne Taşlık Medresesi, İstanbul Mahmud Paşa Medresesi, Edirne Üç Şerefeli Medrese ve Sultan Bayezid Medresesi'ne müderris olarak tayin edilmiştir. Bursa ve İstanbul kadılığı, 1522'de ise Rumeli ile Anadolu kazaskerliklerine yükseltilen Abdülvâsî Çelebi, 1523 yılında tüm görevlerinden feragat edip emekli olmuştur. Kitaplarını Edirne ulemasına bağışlayıp, servetiyle Dimetoka'da medrese ve mektep, Bursa'da da bir mektep inşa ettiren Vâsî Çelebi Mekke'ye yerleşerek münzevi bir hayat sürmüş ve 945/1538 yılında vefat ederek orada defnedilmiştir (Aksoyak \& Kaplan, 2014; Bâdî, 2014: 2/1326; İpekten, vd., 1988: 523; Latîfî, 2000: 554; Mecdî, 1989: 1/394; Riyâzî, 2017: 331; Sehî, 1998: 76; Süreyya, 1996: 5/1654; Tuman, 2001: 2/639).

Tezkirelerde nazik, hoş tabiatlı ve şiire istidadı olan biri diye tanıtılan Abdülvâsî Çelebi için Fâizî "Divan" sahibi olduğundan bahsetmesine rağmen kaydına ulaşılamamıştır (Kayabaşı, 1997: 584). Latîfî ve Sehî Bey ise az sayıda şiirinin bulunduğunu söylemektedir (Latîfî, 2000: 555; Sehî, 1998: 76).

Âşıkın hakkında çok söz söyler imiş dil-bere

Çok söz işidir uyarsa düşmana cânânımız (Bâdî, 2014: 2/1884)

\section{Visâlî}

Visâlî Çelebi Dimetoka'da dünyaya gelmiştir. Ahdî ise tezkiresinde İstanbul doğumlu olduğunu söyler (Ahdî, 2018: 197). Küçük yaşta İstanbul'a gelip II. Bayezid (ö. 918/1512) saltanatında saraya giren Visâlî, şehzade I. Selim'le (ö. 926/1520) yakınlık kurmuş ve onun sultanlık devrinde de yanında bulunmuştur. Kesin vefat tarihi bilinmeyen şairin XVI. yüzyılın ilk yarısında vefat ettiğini söylemek mümkündür (Bâdî, 2014: 3/2003; Tanyldız, 2014; Tuman, 2001: 2/1166).

Türkçe ve Farsça şiir söylemede mâhir, Farsça deyim ve atasözlerini derlemede yetenekli bir şair olarak görülen Visâlî Çelebi’nin elimizde bir gazel ve müfredinden başka eseri bulunmamaktadır (Ahdî, 2018: 197).

Bir menzil ise yeter murâdım nişâneden

Olsam halâs cevr-i kemân-ı zamâneden

Tahsîn şâh-bâz-ı hümâ âşiyâna kim

Rûhânîdir gıdâsı degil âb u dâneden

\begin{tabular}{|c|c|}
\hline Ad & Address \\
\hline 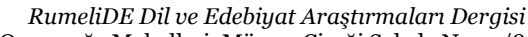 & RumeliDE Journal of $L$ \\
\hline & Osmanağa Mahallesi, Mürver Çiçeği Sokak, No:14/8 \\
\hline KIYE 34714 & Kadıköy - ISTANBUL / TURKEY 34714 \\
\hline $\begin{array}{l}\text { e-posta: editor@rumelide.com } \\
\text { tel: +90 505 7958124, +90 } 216773 \text { o } 616\end{array}$ & $\begin{array}{l}\text { e-mail: editor@rumelide.com, } \\
\text { phone: +90 505 7958124, +90 } 216773 \text { o } 616\end{array}$ \\
\hline
\end{tabular}


Ser-â-pâ bürehne âşık-ı abdâl olup sana

Üryân dâg-1 aşk ile dogmuştum âneden

Ankâ-yı çarh beyza-i mâh ile dogmadan

Mürg-i dili uçurmuş idim âşiyâneden

Tîr-i cefâmı bagrına basmaz çekip demiş

Çekmek Visâlî aramızı yâr yâneden (Bâdî, 2014: 3/2003)

\subsection{Ferecik doğumlu şairler}

\section{Çarhacı Şeyh Ahmed Efendi}

Çarhacı Şeyh Ahmed Efendi Ferecik’te dünyaya gelmiştir. Doğum tarihi bilinmeyen şairin hayatına dair bilgiler de oldukça sınırlıdır. Farsça "tekerlek" anlamına gelen çarha kelimesine Türkçe -cı eki ilavesiyle türetilen kelimeden hareketle Ahmed Efendi'nin tekerlekçi esnafı yahut orduda keşif vazifesinde bulunan ve adına "Çarhacılar" denilen öncü süvari birliğine bağlı bir asker olduğunu söylemek mümkündür (Özcan, 1993: 8/229). Ahmed Efendi hakkındaki net bilgi Ferecikli Halvetî şeyhi Şaban Efendi'ye intisap ettiği, sülûkunu tamamlayı hilafet alınca İstanbul Sultanahmet semti Cankurtaran mahallesindeki Akbıyı Sultan Tekkesi'ne şeyh olarak gönderilmesidir. Bu tekke İstanbul'un fethinde büyük yararlılıklar göstermiş Bayramî dervişlerinden Akbıyı Sultan (ö. 860/1456) adına yaptırılmıştır. Akbıyık Sultan’ın Bursa'ya göçmesinden sonra atıl halde kalan tekke, Sadrazam Köprülü Fazıl Mustafa Paşa (ö. 1102/1691) tarafından tamir ettirilmiş ve şeyhliğine de Çarhacı Ahmed Efendi getirilmiştir (Tanman, 1989: 2/222-223). Başta Çaresiz İlyas Efendi (ö. 1118/1706) gibi pek çok şair sufi yetiştiren Şeyh Ahmed Efendi, 1080/1669 yılında vefat edip Üsküdar Sakızağacı mevkiinde defnedilmiştir (Aslan, 2014; Ayvansarâyî, 2017: 205).

Kaynaklarda herhangi bir eser kaydı bulunmayan Şeyh Ahmed Efendi'nin şiirine Vefeyât-ı Ayvansarâyî’de iki dörtlükle örnek verilmiştir. Fakat bu örnek Nüzhet Ergün’ün "Türk Şairleri” isimli eserinde tanıttığı XVII. yüzyıl saz şairlerinden Çırakçı Miskin'in 43 bentten oluşan "Beynamaz Destanı" adlı şiirinin bir parçadır (Ergün, Tarihsiz: 3/1112).

İşit bî-namaz olana / Ol yüce Mevlâ ne dimiş

Çıksun yirümden gögümden / Gayrı Tanrı bulsun dimiş

Çarhacı Miskin ne dimiş / Bârîye şükr eyle dimiş

Bu sözleri aceb dimiş / Vay ne gâfildir bî-namaz (Ayvansarâyî, 2017: 205)

\section{Hadîdî}

Hadîdî Ferecik’te doğmuştur. Asıl ismi bilinmeyen şair, eğitimini tamamlayınca hatiplik ve müderrislik görevlerinde bulunmuştur. Daha sonra vazifelerinden feragat ederek baba mesleği olan demirciliğe yönelen Hadîdî, hayatını bu şekilde idame ettirmiştir. Zeyniyye tarikatına müntesip bir derviş de olan şair Ferecik’te vefat etmiştir (Bâdî, 2014: 3/2215; Beyânî, 1997: 69; Çelebi, 2010: 2/613; İpekten, vd., 1988: 167; Kınalızâde, 2017: 288; Latîfî, 2000: 222; Riyâzî, 2017: 118; Sehî, 1998: 183; Süreyya, 1996:

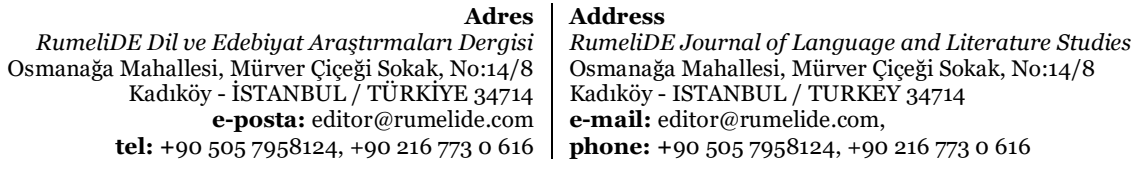


2/656; Tahir, 1972: 3/62; Tevfik, 2017: 212). Ölüm tarihini Sicill-i Osmanî 940/1533 diye gösterirken (Süreyya, 1996: 2/554), Tuhfe-i Nâilî doğru tarihin 968/1560 olduğunu belirtir (Tuman, 2001: 1/189). Hadîdî’nin manzum tarihini yayımlamış Necdet Öztürk ise her iki tarihin de doğru olmadığını ve kesin ölüm tarihinin bilinmediğini söyler (Hadîdî, 1991: XXX).

Demircilikle uğraştığı için şiirlerinde Hadîdî mahlasını kullanan şairin 1299-1523 yılları arası olaylarını barındıran Tevârih-i Âl-i Osman adlı 6646 beyitlik manzum Osmanlı tarihi ile Eğirdirli Hacı Kemal'in mecmuasında 6 (Morkoç, 2003: 2362), Edirneli Nazmî’nin mecmuasında 43 (Nazmî, 2017: 44), Pervâne Bey mecmuasında 36 gazeli (Pervâne, 2017: 2941), Kabîlî ve Peşteli Hisâlî mecmualarında da birer beyti bulunmaktadır (Kabîlî, 2018: 92; Kalyon, 2011: 1406).

Vireli zînet meh-i tâbâna yelken takyesi

Yıkdı dil mülkin idüp vîrâne yelken takyesi

Gûşesi salındugınca boynına ruhsârına

Yaraşur kâkül gibi cânâna yelken takyesi

Per açup lerzân cemâli üzre olmış gûyiyâ

Şem’ine ruhsârınun pervâne yelken takyesi

Sidre tâvûsına benzer dil-ber-i meh-çihrenün

Başladukça bâl açup cevlâna yelken takyesi

Ey Hadîdî ebre benzer ki âftâb üstindedür

Rûmili mahbûbınun merdâne yelken takyesi (Nazmî, 2017: 1661)

\section{Râsim}

Hacı Seyyid Ömer Râsim Efendi 1192/1778 yılında Ferecik'te doğmuştur. Babası Ferecik ahalisinden Mahmud Efendi'dir. İlk eğitimini memleketinde tamamlayıp tahsilini ilerletmek için İstanbul'a giden Râsim Efendi, mezun olunca defterdâr mektubî odasında göreve başlamıştır. İşindeki maharetiyle hâcegânlık rütbesi verilen Râsim, çalıştığı kuruma ser halife olarak atanmıştır. 1828 yllında vuku bulan Rus savaşının zararlarını anlatan bir layiha kaleme almasından dolayı Rodos'a sürgün edilmiştir. Dostlarının araya girmesiyle 1829 yllında affedilip İstanbul'a dönen Râsim Efendi, 1831'de Sayda'da daha sonra da Anadolu ve Rumeli'nin farklı kasabalarında memur olarak bulunmuştur. 1832 senesinde mevkufatçı, 1838 'de maliye tezkirecisi vazifelerini ifa edip bu vazifeden emekli olmuştur. 1845 yllında hac farizasını yerine getirmek üzere Hicaz'a giden Râsim Efendi, 1262/1846 yılında Hicaz'da vefat edip defnedilmiştir (Ârif, 2019: 50; Bâdî, 2014: 3/2216; Çeltik, 2013: 105; Esad, 2018: 126; Fatin, 2017: 150; İnal, 2002: 4/1790; İpekten, vd., 1988:368; Süreyya, 1996: 4/1353; Tuman, 2001: 1/308).

Kendisini tanıtan tezkirelerde şiirleri bulunan, nazım ve nesirde mâhir bir edip görülen Râsim’in ayrıca özel ve resmî mektuplarının derlendiği ve Yapı Kredi Sermet Çifter Kütüphanesi No. 598 ve 767'de kayıtlı bir Münşeat'ı mevcuttur. Halil Çeltik, şairin "Divançe" sahibi olduğunu belirtmesine rağmen herhangi bir kaydına ulaşılamamıştır (Çeltik, 2013: 106).

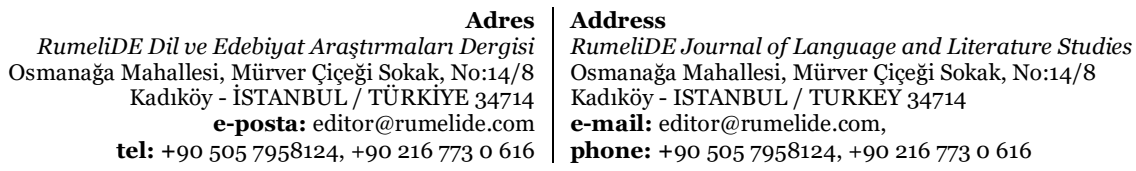


Sanmanız şimdi bendedir gönlüm

Bir şeh-i hüsne bendedir gönlüm

Kıl nevâziş anı garîb itme

Sevdigim çünkü sendedir gönlüm

Kand-i la'l-i lebin sorup gitdi

Ben de bilmem ki kandedir gönlüm

Bir tebessümle şâd olur cânâ

Arzû-mend-i handedir gönlüm

Gâh cevr u gehi cefâ Râsim

Dürlü dürlü muhandadır gönlüm (Fatin, 2017: 150)

\section{Rıfkı Melûl Meriç}

Süleyman Rıfkı Coşkunmeriç 1318/1901 yllında Ferecik’te doğmuştur. Daha çok Rıfkı Melûl Meriç adıyla bilinen şairin babası Saatçi Hafız Mehmed Ali Efendi'dir. Tahsiline memleketinde başlayan Rıfkı Bey bilahare Edirne Sultânîsi'nde okumuştur. Patlak veren Balkan Harbi dolayısıyla ailesiyle birlikte İstanbul'a taşınarak Menba'ul-İrfan İdâdîsi'ni tamamlamıştır. 1917 yılında İstanbul Üniversitesi Tıp Fakültesi'ne girip son sınıfında okulu bırakarak Yüksek Ticaret Mektebi’ne geçmiştir. Burada da aradığını bulamayan Rıfkı Bey, İstanbul Üniversitesi Edebiyat Fakültesi’ne başlayıp 1927 yılında mezun olmuştur. Farklı okullarda öğretmenlik yapan Rıfkı Melûl Bey, 1928'de Ankara Etnografya Müzesi'ne memur olarak atanmıştır. Bir müddet sonra buradan ayrılıp Ankara, Kütahya, Akşehir, Eskişehir ve Adana gibi Anadolu şehirlerinde Türkçe ve edebiyat öğretmenliği yapıp 1936 senesinde İstanbul'a tayin edilmiştir. 1941-1945 yılları arası İstanbul Üniversitesi Edebiyat Fakültesi’nde, 1951'de ise Ankara Üniversitesi İlahiyat Fakültesi’nde öğretim görevliliği yapmıştır. İlahiyat fakültesinde bulunduğu esnada İstanbul'da Güzel Sanatlar Akademisi'nde de dersler vermiş ve bu akademi bünyesinde Türk Sanatı Enstitüsü'nü kurmuştur. 1960’ta Ankara'daki görevinden ayrılıp İstanbul'a dönen Rıfkı Melûl Meriç, kurduğu enstitünün müdürlüğüne geçmiştir. 1383/1964 yılında İstanbul'da vefat eden Rıfkı Bey Rumelihisarı kabristanına defnedilmiştir (Akpınar, 2004: 29/191; İnal, 2002: 4/1935; Tevfikoğlu, 1986: 13; Timurtaş, 1964:51; Ülken, 1964: 135-137).

Küçük yaşlarında şiir söylemeye başlayan ve cumhuriyet dönemi Türk şiirinde klasik yazım geleneğini sürdürenlerden olan Rıfkı Melûl Meriç ayrıca mimarî, hat, musiki, ciltçilik, tezhip gibi sanatın diğer alanlarıyla da meşgul olmuştur. Yahya Kemal Beyatı (ö. 1377/1958), Mahmut Kemal İnal (ö. 1376/1957), Ahmet Hamdi Tanpınar (ö. 1381/1962), Hilmi Ziya Ülken (ö. 1393/1974) gibi Türk edebiyat ve fikir dünyasının mühim isimleriyle yakın dostluklar kuran Rıfkı Bey çok yönlü bir münevverdir (Kara, 2003: 1-27). Klasik üslupta, melamî ve rindâne söyleyişe sahip Inkıraz (Meriç, 1928) ve Hilmi Ziya Ülken'in şerhiyle basılan Rubaiyyât-ı Melûl I (Meriç, 1951) adlı şiir kitapları bulunmaktadır. Bu kitaplara girmemiş şiirleri ise farklı makale ve eserlerde derlenmiştir (Dinçer, 2017: 52-76; Tevfikoğlu, 1979: 25-26; Tevfikoğlu, 1986: 84). Yine Türk Tezyînî Sanatları: Yazı Sanatı (Meriç, 1937), Türk Nakış Sanatı Tarihi I. Cilt: Vesikalar (Meriç, 1953), Türk Cilt Sanatı Tarihi Araştırmaları (Meriç, 1954),

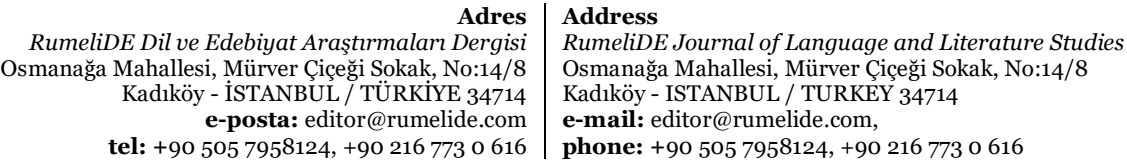

RumeliDE Journal of Language and Literature Studies

Osmanağa Mahallesi, Mürver Çiçeği Sokak, No:14/8

Kadıköy - ISTANBUL / TURKEY 34714

e-mail: editor@rumelide.com,

phone: +90 505 7958124, +90 2167730616 
Mimar Sinan Hayatı, Eseri I (Meriç, 1965) isimli eserleriyle muhtelif dergilerde yayımlanmış makaleleri mevcuttur (Akpınar, 2004: 29/191; Kara, 2003: 22; Tevfikoğlu, 1986: 55).

Rûh epsem olur aşk-ı nev'-i mu'tezilimden

Aşk âteş alur rûh-i ter-i münfa'ilimden

Mızrâbımı bir âh ile bir kerre vurunca

Bin âh-ı felek-sûz çıkar târ-ı dilimden

Bir âh ediversem tutuşur mülk-i hafâda

Ervâh u melâik nefes-i müşta’ilimden

Uşşâk yanup öğrenecektir ne imiş aşk

Fânilere miras eser-i müntakilimden

Elbette yanar sîne-i kabrimdeki güller

Her zerre-i muhrik-sıfat-ı âh u gilimden (Tevfikoğlu, 1986: 91)

\subsection{Gümülcine doğumlu şairler}

\section{Dürrî}

Dürrî Efendi Gümülcine'de doğmuş ve yaşamış şairlerdendir. Tezkirelerde ismi geçmeyen ve hayatı hakkında yeterli bilgi bulunmayan şairin şiirlerinden iyi bir tahsil gördüğü anlaşılmaktadır. Pek çok devlet adamına kasideler sunmuş olan Dürrînin ölüm tarihi bilinmemekle beraber, divanındaki 1053/1644 yllını gösterir tarih manzumelerinden hareketle XVII. asrın ilk yarısında henüz hayatta olduğunu söylemek mümkündür (Ergün, Tarihsiz: 4/1188; Everdi, Kutlu, \& Kara, 1980: 2/400).

Âşıkane ve sade bir üslupla şiirlerini kaleme almış olan Dürrînnin Divan’ı (Kılıç, 2010), Divan’ının içinde yer alan Gümülcine Şehrengizi (Yazar, 2007) ile Moton Şehrengizi mevcuttur (Yazar, 2009).

Dilber-i bî-vefâya aşk olsun

Âşık-ı bî-nevâya aşk olsun

Nûş olan dest-i yâr-i meh-rûdan

Bâde-i pür safâya aşk olsun

Gam-ı gül-i pür-gubâr olursa gönül

Sâgar-1 dil-güşâya aşk olsun

Tekye-i aşk-1 dil-rübâda müdâm

Çekilen hûy u hâya aşk olsun

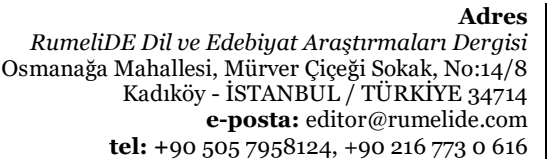

Adres Osmanağa Mahallesi, Mürver Ciçeği Sokak, No:14/8 e-posta: editor@rumelide.com tel: +90 505 7958124, +902167730616
Address

RumeliDE Journal of Language and Literature Studies Osmanağa Mahallesi, Mürver Çiçeği Sokak, No:14/8

Kadıköy - ISTANBUL / TURKEY 34714

e-mail: editor@rumelide.com,

phone: +90 5057958124 , +90 2167730616 
Derd-i aşka tekmîl eylemede

Dürrî-i mübtelâya aşk olsun (Kılıç, 2010: 115)

\section{Esad}

Mehmed Esad Efendi Gümülcine doğumludur. Babası Gümülcine Kır Mahalle Medresesi müderrislerinden bir zattır. Hayatı ve kesin vefat tarihi bilinmeyen şairin, 1320/1902 ile 1322/1904 yıllarında Sultan II. Abdülhamid’in (ö. 1842/1918) doğum gününü tebrik için kaleme aldığı gazellerinden hareketle XX. yüzyılın başlarında henüz hayatta olduğunu söylemek mümkündür (Bâdî, 2014: 3/2247).

Kaynaklarda ve kataloglarda eser kaydı bulunmayan Mehmed Esad Efendi’nin elimizde sadece bu tebrik gazelleri mevcuttur (Esad, 1904: 2).

Taht-pîrâ-yı hilâfet hazret-i Abdülhamîd

Hâver-i sa'd ü şereften âleme oldu bedîd

Sâye-i adlinde geldi âleme feyz-i cedîd

Eylesin feyyâz-ı mutlak ömr ü ikbâlin mezîd

Yevm-i mes'ûd-i vilâdettir bu gün ey kâriîn

Zîver-i mehd-i şühûd oldu emîru'l-mü'minîn

Ömr ü iclâlin mezîd kıl yâ ilâhe’l-âlemîn

Tâ ebed iclâl ile olsun melâz-ı müslimîn

Geçmedi mislin senin a'sâr-ı sâbıkta şehâ

Sen gibi bir pâdişâhın ugruna cânlar fedâ

Eyliyor Esad kulun ez-cân u dil böyle duâ

Ey şehen-şâh-ı mu'azzam şevketinle bin yaşa (Bâdî, 2014: 3/2247)

\section{Esad}

Mehmed Esad İleri Bey 1298/1882 yllında Gümülcine’de doğmuştur. Babası Gümülcine mebusu Müderris Mehmed Hilmi Efendi'dir (ö. 1336/1918). Tahsilini memleketinde tamamlayan Esad Bey, Gümülcine İdâdîsi'nde muallimlik ve Gümülcine Yeni Camii’nde kürsü şeyhliği vazifelerinde bulunmuştur. İttihat ve Terakki Cemiyeti'nin Gümülcine reisliğini yürüten Esad Bey, 1913 yllında kurulan Garbî Trakya Hükümet-i Müstakilesi'nde de etkin rol oynamıştır. 23 Eylül 1913’te imzalanan İstanbul Antlaşmasında Garbî Trakya Hükümet-i Müstakilesi’nin feshedilip, Batı Trakya'nın Bulgaristan'a bırakılmasının kararlaştırılması ve 25 Ekim 1913 tarihinde bu devletin tarih sahnesinden çekilmesi üzerine ailesiyle birlikte önce İstanbul'a ardından da Aydın'a hicret etmiştir. Kuva-yı Milliye saflarında pek çok cephede savaşan Esad Bey; ordu müftülüğü, Hilâl-i Ahmer reisliği ile Aydın Sultânîsi din dersleri ve Farsça muallimliklerinde bulunmuştur. I. Dönem Aydın ve II. Dönem Menteşe mebusluklarıyla Meclis'e giren Mehmed Esad Bey, muhtelif komisyonlarda görev aldıktan sonra emekli

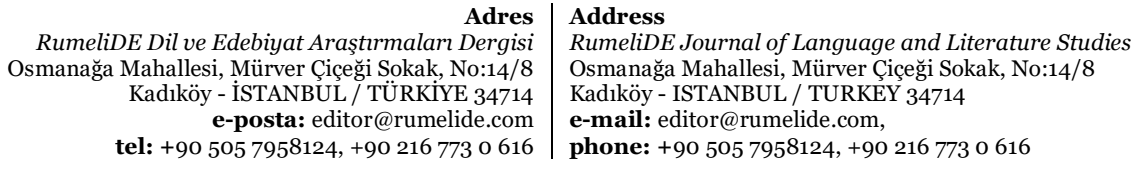


olup Aydın'a yerleşmiştir (TBMM, 2020). 1376/1957 yılında geçirdiği trafik kazasında hayatını kaybeden Esad Bey, İzmir Bornova Kokluca mezarlı̆̆ına defnedilmiştir (Çakar, 2018: 5; Tunalı, 2007: 81-100).

Ömrünü mücadelelerle geçiren Mehmed Esad Bey aynı zamanda kalemi güçlü bir münevverdir. Milliyetçilik, vatan sevgisi, harp yıllarında yaşanan zulümler, dinî bahisler ve bunlara bağlı olarak şiirler yazmış olan Esad Bey’in şu eserleri bulunmaktadır: Reşâhat-ı Hikemiyye (Esad, 1911), Cihâd-ı Ekber (Esad, 1914), Hilâl-i Ahmer (Esad, 1916), Düşündüklerim, Dileklerim, Emeklerim (Esad, 1922), Halk Şïrleri (Esad, 1923), Türk Dilinde Kinâyât (Esad, 1924; Trraş \& Ertürk, 2017), Verin Zavallhlara (Esad, 1924b), Türk Dilinde Darb-ı Meseller (Esad, 1925; Gümüşatam, 2017), Bu Suya Sen de Eğil (Esad, 1934), Hadîs-i Şerîf Tercümesi (Esad, 1945), Sözlerin Özü Atalar Sözü (Esad, 1947), Rahmetli İmam Birgivî (Esad, 1954). "Kadınların Vatan İşlerine Girmesine Dair" isimli bir eserinden daha bahsedilmesine karşın kaydına ulaşılamamıştır (Çakar, 2018: 70).

Bağrımla çevrelenen bir göle azar azar

Şiirlerim ruhumdan birer yaş gibi sızar

Işıklarında gülen ağlayan bir renk varda

Bir nağme olur gönlüm titrer bu damlalarda

Kimi anne bakışı gibi tatlı sıcaktı

Kimi bağrımı yaran sihirli bir bıçaktı

Kimi üzgün gözlerde buğulanan bir inci

Kimi andırıyordu titreyen bir sevinci

Kimini bulutlardan yasemin bir el attı

Kimini coşkun seller firtınalar yarattı

Bütün bunların hepsi süzülüp birer birer

Yüreğimde ışıyan bir göle döküldüler

İşte benim hayatım ölmez eserim budur

Kâh ses gibi ürperen kâh durulan sudur

Sevgilim gülme bana bu sudan eser diye

Düştü suya bir ömür bütün emekler diye

Sen ki hülyalarımla beslenen bir çiçeksin

Bu göle biraz eğil kendini göreceksin (Çakar, 2018: 81)

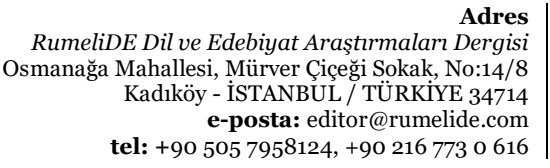

Adres Osmanağa Mahallesi, Mürver Cicçeği Sokak, No:14/8 e-posta: editor@rumelide.com tel: +90 505 7958124, +902167730616
Address

RumeliDE Journal of Language and Literature Studies Osmanağa Mahallesi, Mürver Çiçeği Sokak, No:14/8

Kadıköy - ISTANBUL / TURKEY 34714

e-mail: editor@rumelide.com

phone: +90 5057958124 , +90 2167730616 


\section{Nahîfî}

Nahîfî Ahmed Efendi Gümülcine’de doğmuştur. Babası Gümülcine eşrafından Hacı Edîb Bey’dir. İlk tahsilini memleketinde alan Nahîfî sonra Edirne Askerî Okulu'nu ve İstanbul Harbiye Mektebi’ni tamamlamıştır. Mezuniyetini müteakip askerî vazifeyle Manastır’a gönderilen Nahîfí, 1874 yılında Bosna'da vilayet defterdârı olarak görev yapan eniştesi Hacı Muhammed Râşid Efendi vesilesiyle ve yabancı dil bildiği için Bosna vilayeti umûr-i ecnebiye kalemine baş defterdâr olarak tayin edilmiştir. Bir müddet sonra istifa ederek İstanbul'a dönen Nahîfî, devlet aleyhtarı söylemlerinden dolayı Kıbrıs'a sürgün edilmiştir. Affedilince Gümülcine tahrirat müdürlüğüne getirilen şair, asi davranışları sebebiyle yine azledilmiştir. Düşük rütbeli memurluklarda görevlendirilen Nahîfî, dava vekili olarak bulunduğu İstanbul'da işlediği kabahatlerden dolayı tekrar azledilip Trablusgarb'da yaşamaya mahkûm edilmiştir. Ne zaman ve nerede vefat ettiği bilinmeyen şairin ilk göreve başladığı tarihe bakarak XIX. yüzyıl sonları yahut XX. başlarında vefat ettiğini söylemek mümkündür (Bâdî, 2014: 3/2247).

Ahmed Nahîfî Efendi'nin eser sahibi olduğuna dair kaynaklarda ve kütüphanelerde herhangi bir kaylt bulunmamakla beraber Riyâz-ı Belde-i Edirne'de bir gazeli mevcuttur.

Mülevven müje-i çeşm-i yârsın yâ leyl

Şu’â-i bedrile âvîze-dârsın yâ leyl

Şifâ bulur dil-i uşşâk halvetinde senin

Hazîn ü nâle-zen-i yâr-ı gârsın yâ leyl

Nüzûl-i jâle-i çeşmin gören sanar şebnem

Tulû'-i şems-i nigeh-dâr u zârsın yâ leyl

Siyâh zülfüne kıldın beni esîr o mehin

Ne dil-şikâr-ı letâfet-nisârsın yâ leyl

Kalırdı vâdi-i hayrette olmasa himemin

Nahîfi-i mihen-âlûda yârsın yâ leyl (Bâdî, 2014: 3/2248)

\section{4. İskeçe doğumlu şairler}

\section{Pâkî}

Pâkî İskeçe'de dünyaya gelmiştir. Pâkize Sultan ve Pâkî Baba isimleriyle de anılan şair, Dimetoka kasabasına bağlı Ruşenler köyünde bulunan Seyyid Ali Sultan Dergâhı'nın dokuzuncu postnişinidir. Pâkî Baba 1628-1644 yılları arasında bu dergâhın şeyhliğini yürütmüştür. 1053/1644 yllında vefat eden sufi şair, dergâhın Dolu Babalar haziresine defnedilmiştir. Herhangi bir esere sahip olduğu bilinmeyen Pâkî Baba'nın elimizde bir şiiri mevcuttur (Koca, 2005: 276; Yıldız, 2015).

Çok şükürler olsun sürdüm yüzümü

Eşiğine Seyyid Ali Sultân'ın

Sıdk ile bağladım ben de özümü

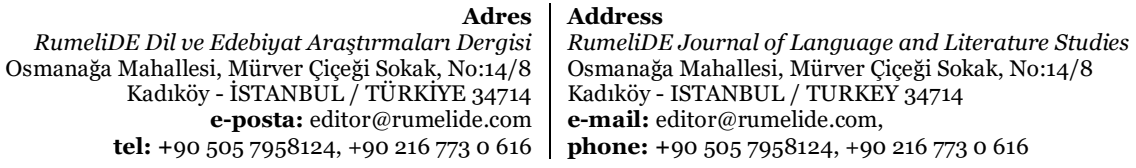


Eşiğine Kızıl Deli Sultân'ın

Gelibol'dan geçti Hakk'a dayandı

Tahta kılıç al kanlara boyandı

Burhânın görenler geldi inandı

Eşiğine Kızıl Deli Sultân'ın

Koru Yaylası'ndan attı şişini

Baba Pınarı'nın deldi taşını

Kurklar belî dedi koydu başını

Eşiğine Kızıl Deli Sultân'ın

Pâkî’nin ezelden vardır îmânı

Seyyid Ali'dir derdinin dermânı

Râhında fedâdır baş ile cânı

Eşiğine Kızıl Deli Sultân'ın (Koca, 1990: 894)

\section{Rif'at}

Mîr-i Alem-zâde Halil İbrahim Rif’at Bey İskeçe'de doğmuştur. Babası İskeçe a’yânı Mîr-i Alem Topuzlu Mustafa Ağa'dır. Tahsilini memleketinde tamamladıktan sonra İstanbul'a giden Rif'at Bey, sabık Paris büyükelçisi Abdürrahim Muhib Efendi’nin (ö. 1236/1821) divan-ı hümayun beylikçiği görevine başlamıştır. Vazifesindeki başarısı ve dürüstlüğüyle takdir kazanan Rifat Bey bilahare Muhib Efendi’nin kızı ve kendisi gibi şair olan Nesibe Safvet Hanım'la (ö. 1252/1837) evlenmiştir (Ceyhan, 2000: 318). 1834 senesinde Havâs-ı Refi'a kazası mollası olan Rif'at Bey mevleviyet süresini tamamlayamadan 1251/1835 yllında vefat etmiş ve Mihrişah Valide Sultan Türbesi yanındaki kabristanda, babasının mezarının yakınına defnedilmiştir (Bâdî, 2014: 3/2252; Fatin, 2017: 197; İnal, 2013: 5/2609; Süreyya, 1996: 5/1395; Tuman, 2001: 1/360).

Başarılı bir şair olarak görülen Halil İbrahim Rif'at Bey'in Güleşen-i Hurremî adında II. Mahmud'un (ö. 1255/1839) kızı Saliha Sultan'la (ö. 1259/1843) Halil Rif’at Paşa'nın (ö. 1271/1856) düğününü konu edinen 818 beyitlik surnâmesi (Arslan, 2008) ile II. Mahmud methiyeleri ve dönemsel olayların anlatıldığı Âyine-i Zafer isimli manzum eseri bulunmaktadır (Rif at, 2019). Ayrıca kaynaklarda "Divan" sahibi olduğu belirtilmesine karşın herhangi bir kaydına ulaşılamamıştır.

Câna tîr-i kemândır gamzen

Nîze-dâr-ı cihândır gamzen

Gâret-i hânmân-ı cân u dile

Hançer-i hûn-çekândır gamzen

Sîne-i âşıka urur zahmı

Neyleyem bî-emândır gamzen

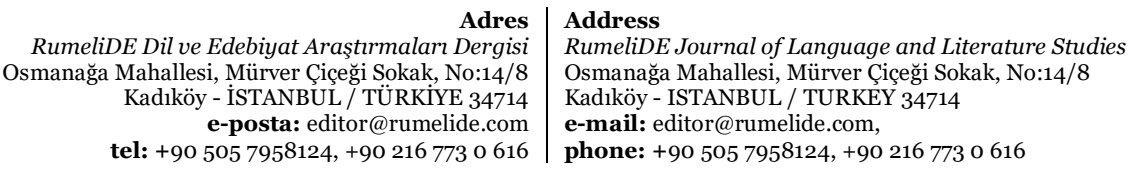


Bir görünmez belâ imiş hâsıl

Fitnedir hem yamândır gamzen

Gerçi zâhirde yog ise eseri

Âleme rây-gândır gamzen

Kâkülü kıssası dolandı dile

Sâ’il-i în u ândır gamzen

Sâbit oldu tevâtüren Rif'at

Rüstem-i Dâstândır gamzen (Fatin, 2017: 196)

\section{Sıdkî}

Mehmed Sıdkî Bey 1299/1882 yılında İskeçe'de doğmuştur. Babası memur İbrahim Hilmi Bey’dir. Tahsiline memleketinde başlayıp İstanbul'da devam ettiren Sıdkî Bey, Hukuk Mektebi’nden mezun olmuştur. Öğrencilik dönemlerinde "İrtika, Musavver-i Fünûn ve Edeb, Terakki ve Malûmat" mecmualarında yazarlık yapan Sıdkî, bu yazılarından dolayı 1906 yılında önce Erzurum'a sonra Erzurum'un Hınıs ilçesine sürgün edilmiştir. Hukuk Mektebi'nden hocası Nazım Bey, Erzurum valiliğine atanınca affedilip "İstanbul'da kalmamak ve yazı yazmamak" şartıyla Gümülcine'ye gönderilmiştir. Gümülcine'de mutasarrıf Mazhar Müfid Kansu (ö. 1367/1948) vesilesiyle İttihad ve Terakki Cemiyeti’ne katılan Sıdkî, II. Meşrutiyet'in (1908) ilanını müteakip önce Drama'ya sonra da Selanik'e geçip Kâinat gazetesini yayımlamıştır. 1910 yılında edebiyat muallimliği sınavına girip kazanan Sıdkî Bey, Edirne Sultânîsi’ne edebiyat öğretmeni olarak tayin edilmiştir. I. Dünya Savaşı'nın (1914-1918) başlamasıyla Trakya-Paşaili Müdafaa-i Hukuk Cemiyeti’ne katılan Mehmed Sıdkî, Yunanistan tarafından idama mahkûm edilmiştir. Bulgaristan'a iltica edip, Eskicuma Mekâtib-i İslamiye okulu müdürlüğünde bulunduktan sonra İstanbul Kız Lisesi, Edirne Sultânîsi ve nihayetinde Kadıköy Erkek Orta Mektebi’ne atanmıştır. 1351/1932 yılında İstanbul'da vefat eden Mehmed Sıdkî Bey Karacaahmet mezarlı̆̆ına defnedilmiştir (Bâdî, 2014: 3/2252; Cin, 2019; İnal, 2002: 4/2169; Yalçın, 2010: 2/699).

Küçük yaşta babasının yönlendirmesiyle şiire merakı başlayan Mehmed Sıdkî Bey'in gazete yazılarından başka, Leylâk hikâyesi (Sıdkî, 1319/1902) ve Hüsn-i Melûl adlı şiir kitabı mevcuttur (Sıdkî, 1327/1911). Ayrıca İbnü'l Emin neşredilmiş "Mezar, Ömr-i Harâb, Serab, Muhaciret" ve basılmamış "Kara Günler" ile "Meriç Ağlarken" isimli kitaplarından bahsetmesine rağmen herhangi bir kaydına ulaşılamamıştır (İnal, 2002: 4/2169-2170).

Zemîn ser-tâ-be-pâ aks-âver-i envâr-ı lâhûtî

Semâ yekser sunûf-i saf-nümâ-yı reng-i nâsûtî

Çiçekler neşr-i bûy şekker ile kuşlar sürûd ile

Çemenler nazra-pîrâ inkişâf-ı dil rübûd ile

Nevâlar muhteziz gül gonceler âheng-i nâ-mahdûd

Bu günden iktibâs-ı nûr ederler her taraf mes'ûd (Bâdî, 2014: 3/2252)

$$
\begin{aligned}
& \text { Adres Address } \\
& \text { RumeliDE Dil ve Edebiyat Araştırmaları Dergisi } \quad \text { RumeliDE Journal of Language and Literature Studies } \\
& \text { Osmanağa Mahallesi, Mürver Çiçeği Sokak, No:14/8 } \quad \text { Osmanağa Mahallesi, Mürver Çiçeği Sokak, No:14/8 } \\
& \text { Kadıköy - İSTANBUL / TÜRKIYE } 34714 \text { Kadıköy - ISTANBUL / TURKEY } 34714 \\
& \text { e-posta: editor@rumelide.com e-mail: editor@rumelide.com, } \\
& \text { tel: +90 } 5057958124,+902167730616 \text { phone: +90 505 7958124, +90 } 2167730616
\end{aligned}
$$


Tablo 1: Şehirlere göre Batı Trakyalı şairler

\begin{tabular}{|c|c|c|c|c|}
\hline \multicolumn{5}{|c|}{ Dimetoka Doğumlu Şairler } \\
\hline No. & İsim/Mahlas & Vefat Tarihi & Vefat Yeri & Mesleği/Tasavvufî Kimliği \\
\hline 1 & Fehîm & $1286 / 1869$ & Edirne & Gümrük Kâtibi \\
\hline 2 & Hayâlî & $930 / 1524$ & Edirne & Kadı \\
\hline 3 & Remzî & $1296 / 1878$ & Edirne & Edirne İdâdîsi’nde Öğrenci \\
\hline 4 & Rızâyî & $985 / 1577$ & Kudüs & Kadı \\
\hline 5 & Sâdık Abdal & XV. yüzyll & Dimetoka & Bektâşî Dervişi \\
\hline 6 & Silahdâr S. Mehmed & $1170 / 1757$ & Mekke & Sadrazam/Muhafiz \\
\hline 7 & Vâsî & $945 / 1538$ & Mekke & Kazasker \\
\hline 8 & Visâli & XVI. yüzyıl & Bilinmiyor & Sultan I. Selim’in Şairi \\
\hline \multicolumn{5}{|c|}{ Ferecik Doğumlu Şairler } \\
\hline 1 & Çarhacı Ahmed Ef. & $1080 / 1669$ & İstanbul & Halvetî Şeyhi \\
\hline 2 & Hadîdî & XVI. yüzyıl & Ferecik & Demirci/Zeynî Dervişi \\
\hline 3 & Râsim & $1262 / 1846$ & Hicaz & Memur \\
\hline 4 & Rıfkı Melûl Meriç & $1383 / 1964$ & İstanbul & Akademisyen \\
\hline \multicolumn{5}{|c|}{ Gümülcine Doğumlu Şairler } \\
\hline 1 & Dürrî & XVII. yüzyıl & Bilinmiyor & Şair \\
\hline 2 & Esad & XX. yüzyll & Bilinmiyor & Şair \\
\hline 3 & Esad & $1376 / 1957$ & İzmir & Mebus \\
\hline 4 & Nahîfî & XX. yüzyll & Bilinmiyor & Memur \\
\hline \multicolumn{5}{|c|}{ İskeçe Doğumlu Şairler } \\
\hline 1 & Pâkî & $1053 / 1644$ & Dimetoka & Bektâşî Şeyhi \\
\hline 2 & Rifât & $1251 / 1835$ & İstanbul & Eyüp Mollası \\
\hline 3 & Sidkî & $1351 / 1932$ & İstanbul & Öğretmen \\
\hline
\end{tabular}

\section{Sonuç}

Rumeli gerek klasik Türk edebiyatına gerekse Türk tasavvuf edebiyatına pek çok şair yetiştirmiş önemli bir kültür havzasıdır. Yenice Vardar, Üsküp, Sofya, Prizren gibi "şairler menbaı" olarak bilinen şehirleriyle beraber bir dönem rağbet görüp sonra ilgiyi kaybetmiş veya yakınındaki büyük şehrin gölgesinde kalmış fakat değerler barındıran kasabaları da mevcuttur. Bu yerlerden birisi de Batı Trakya'dır. Anadolu'nun Avrupa'ya açılan kapısı olan Batı Trakya, edebî ve kültürel anlamda mezkûr şehirler kadar ön plana çıkamasa da kasabalarındaki iç dinamikleriyle muhitler kurmuş ve Türk edebiyatına 19 şair kazandırmıştır. Başka yerde doğmasına rağmen Batı Trakya'ya gelip vefat eden şairler de listeye eklendiğinde sayı muhakkak artacaktır. Fakat bu çalışmada sadece Batı Trakya kasabalarında doğan şairler değerlendirmeye alınmıştır.

Tablodaki tasniften görüleceği üzere şair yetiştirmede en velûd Batı Trakya kasabası sekiz kişiyle Dimetoka'dır. Onu dörder şairle Ferecik ve Gümülcine takip eder. En az şairi bulunan kasaba ise üç kişiyle İskeçe'dir. Kültürel gelişmeler siyasî güç ve hâkimiyeti izlemesine rağmen bu gelenek Batı Trakya'da farklı seyretmiştir. XIV. asrın ikinci yarısında Osmanlı idaresine giren bölgeye Türk İslam

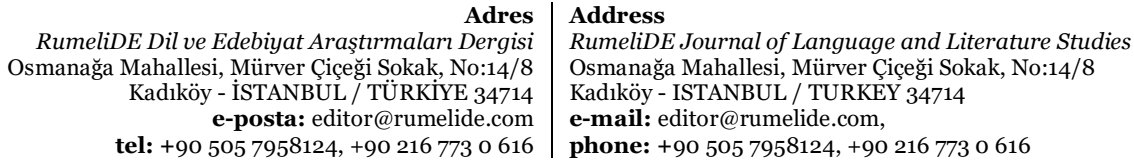


kültürünün yerleşmesi yüz yll sürmüş ve kayıtlara geçen ilk şair XV. yüzyllda ortaya çıkmıştır. Bu tarihten sonra sayı artmış ve XVI. yüzyılda beş şair yetişmiştir. Müteakip asırlarda sayı azalmış ve XVII. yüzyılda üç, XVIII. yüzyılda da bir şair bulunmuştur. Osmanlı idaresinin zayıflamasına karşın edebî anlamda bölge tekrar hareketlenmiş ve XIX. yüzyllda dört; Osmanlı idaresinin nihayet bulduğu XX. yüzyılda da beş şair yetişmiştir. İdarî istikrarın bozulmasına rağmen Batı Trakya’nın edebî ve kültürel anlamda canlı olmasının en önemli sâiki tamamen Türk nüfustan oluşmasıdır. Diğer Rumeli şehirlerinde din birliği olsa da farklı etnik tabakalardan oluşan Osmanlı toplumu ulusçuluk hareketlerinden daha kolay etkilenmiş ve tabii olarak bu durum edebiyatta da kendini göstererek ortaya konulan eserleri Türk edebiyatı değil fakat İslam edebiyatı içerisinde değerlendirmeye uygun hale getirmiştir. Batı Trakya'da ise Türk edebiyatı dilsel olarak değil nitelik ve nicelik bakımından değişime uğramıştır.

Osmanlı devri Batı Trakya'sında şiiri çağın edebî akımlarının yanında nitel ve nicel bakımdan etkileyen medrese ve tekkelerdir. İlim ve irfan merkezi bu kurumlar şairlerin de beslendikleri mahfiller olup tesirleri şehirlere göre farklllık göstermektedir. Gümülcine'de tamamen medrese ekolü hâkimken, Dimetoka ve İskeçe'de medrese baskın olmasına rağmen dergâhlarda yetişmiş sufi şairler de mevcuttur. Ferecik’te ise tasavvufî ekol daha güçlüdür. Batı Trakyalı şairlerden yedisi (Dürrî, Esad, Esad, Hayâlî, Rızâyî, Silahdâr Seyyid Mehmed, Vâsî) Batı Trakya medreselerinde eğitim almış, sekizi (Fehîm, Nahîfí, Râsim, Remzî, Rıfkı Melûl Meriç, Rifaat, Sıdkî, Visâlî) ilk eğitimini Batı Trakya’da tamamladıktan sonra Edirne ve İstanbul'da tahsiline devam etmiş yahut memuriyete başlamış, üçü ise (Çarhacı Ahmed Efendi, Pâkî, Sâdık Abdal) dergâhlarda yetişmiş sufi şairlerdendir. Ferecikli Hadîdî ise hem medrese hem de tekke geleneğinden istifade etmiş şair olarak diğerlerinden ayrılmaktadır.

XV. yüzyıldan XIX. yüzyıla kadar Batı Trakyalı şairlerin şiirleri ve eserleri incelendiğinde tür, şekil, mazmun ve tema kullanımında klasik şiir geleneğine bağlı kaldıkları görülür. XX. asır şairlerinin eserlerine bakıldığında ise klasik edebiyat çizgisinin kısmen devam ettirilmesiyle beraber manzum eserlerin yerini nesre bırakmaya başladığı, şiir dilinin sadeleştiği, şiirde edebî sanatların kullanımın azaldığı ve aşk, âşık, sevgili gibi temaların yerini milliyetçilik, vatan sevgisi, dinî bahisler, hicret, zamandan şikâyet, geçmişe özlem, kadim değerler ve güzelliklerin aldığı görülür. Bunun sebebi kuşkusuz yaşanan savaşlar, idarî, siyasî ve sosyal karmaşalar olmakla beraber medrese ve tekkelerin kapanıp buralarda görevli kişilerin Anadolu topraklarına göç etmesidir. Kültür ve sanat mahfillerinin kaybolması doğal olarak edebiyatta nitelik kaybını doğurmuştur. Günümüzde azınlık olarak yaşayan Batı Trakya Türklerinin ortaya koydukları edebî ürünler de XX. asırda şekillenmiş edebî akımın devamı olarak; Yunan zulmü, azınlık sorunları, hikâye, deneme, çocuk şiir ve masalları gibi konu ve türlerde fakat sanat değeri zayıf şekilde sürdürülmektedir (Bkz. İsen, 1997: 533).

Bu makale Osmanlının Rumeli'de ilk fetihlerini gerçekleştirdiği, en uzun hâkimiyetinde tuttuğu Batı Trakya ve kasabalarının kısa tarihçesinin anlatılıp edebî muhitlerinin belirlenmesi ile Batı Trakya'da doğmuş şairlerin ve bu şairlere ait eserlerin tespiti üzerine kurulmuştur. Çalışma ayrıca günümüz Batı Trakya Türk edebiyatı üzerine yapılan araştırmalarda ihmal edilen Lozan Antlaşması öncesi edebî hayatı, sanat ortamlarını ve şairlerini tanıtarak yeni incelemeler için bölgenin tarihî arka planını ve edebî serencamını görme firsatı verecektir. Bu sayede Batı Trakya'nın kültür ve sanat hayatı daha iyi kavranacak, edebî varlı̆̆ı doğru şekilde analiz edilebilecek ve kadim kültür coğrafyamızın zenginliği artacaktır.

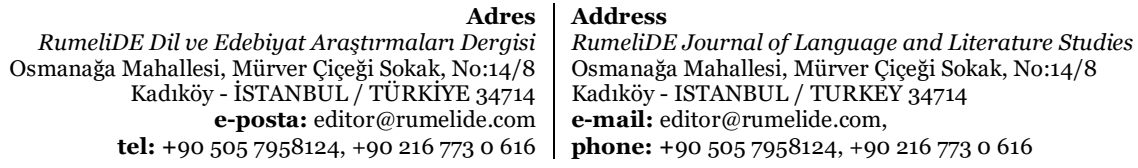

RumeliDE Dil ve Edebiyat Araşttrmaları Dergisi Kadıöy - İSTANBUL / TÜRKIYE 34714 tel: +90 505 7958124, +902167730616 


\section{Kaynakça}

Abdal, S. (2019). Divan. (Haz. H. D. Gümüşoğlu). İstanbul: Dörtkapı.

Ağanoğlu, H. Y., Bayram, S., \& Yıldıztaş, M. (2009). Osmanlı Belgelerinde Batı Trakya. İstanbul: Devlet Arşivleri Genel Müdürlüğü.

Ahdî, B. (2018). Gülşen-i Şu'arâ. (Haz. S. Solmaz). Ankara: Kültür ve Turizm Bakanlı̆̆ Yayınları. https://ekitap.ktb.gov.tr/TR-201251/ahdi-gulsen-i-suara.html (Erişim Tarihi: 19.06.2020)

Akpınar, T. (2004). "Rıfkı Melûl Meriç". Türkiye Diyanet Vakfı İslam Ansiklopedisi, XXIX, 191-192. İstanbul: Türkiye Diyanet Vakf.

Aksoyak, İ. H., \& Kaplan, Y. (2014). "Abdülvâsî". Türk Edebiyatı İsimler Sözlüğü. http://teis.yesevi.edu.tr/madde-detay/vasii-abdulvasi-abdulvasi-vasii (Erişim Tarihi: 26.09.2020)

Ârif, H. B. (2019). Tezkiretü'ş-Şu'arâ. (Haz. M. N. Çınar). Ankara: Kültür ve Turizm Bakanlığı Yayınları. https://ekitap.ktb.gov.tr/TR-240610/seyhulislam-arif-hikmet-bey-tezkiresi.html (Erişim Tarihi: 13.06.2020)

Arslan, M. (2008). Osmanlı Saray Düğünleri ve Şenlikleri I. İstanbul: Çamlıca.

Aslan, Ü. (2014). "Çarhacı". Türk Edebiyatı İsimler Sözlüğü. http://teis.yesevi.edu.tr/maddedetay/carhaci-seyh-ahmed-efendi (Erişim Tarihi: 19.09.2020)

Atâî, N. (1989). Hadâiku'l-Hakâik fî Tekmileti'ş-Şakâik, Şakâik-i Nu'mâniye ve Zeyilleri. (Haz. A. Özcan). İstanbul: Çağrı.

Ayvansarâyî, H. H. (2017). Vefeyât-ı Ayvansarâyî (Haz. R. Ekinci). Ankara: Kültür ve Turizm Bakanlı̆̆ı Yayınları. https://ekitap.ktb.gov.tr/TR-194287/vefeyat-i-ayvansarayi.html (Erişim Tarihi: 31.05.2020)

Bâdî, A. E. (2014). Riyâz-ı Belde-i Edirne. (Haz. N. Adıgüzel, \& R. Gündoğdu). Edirne: Trakya Üniversitesi.

Baş, H. (2005). Unutulan Batı Trakya Türkleri. İzmir: Umay.

Beyânî, M. (1997). Tezkiretü'ş-Şu'arâ. (Haz. İ. Kutluk). Ankara: Türk Tarih Kurumu.

Bıçakçı, İ. (2003). Yunanistan'da Türk Mimarî Eserleri. İstanbul: İSAR Vakfı.

Bozcu, F. (2017). 14.-15. Yüzyll Erken Dönem Osmanlı Tarihinde Bir Saray Şehri: Dimetoka. Yüksek Lisans Tezi, Başakşehir Üniversitesi Sosyal Bilimler Enstitüsü, İstanbul.

Ceyhan, A. (2000). Ahmed Muhtar Beyin Şair Hanımlarımız Adlı Eseri. Selçuk Üniversitesi Türkiyat Araştırmaları Dergisi(8), 299-350.

Cin, H. (2019). "Mehmet Sitkı". Türk Edebiyatı İsimler Sözlüğü. http://teis.yesevi.edu.tr/maddedetay/mehmet-sitki (Erişim Tarihi: 24.09.2020)

Çakar, S. (2018). Esat İleri (Hayatı ve Faaliyetleri). Yüksek Lisans Tezi, İzmir Kâtip Çelebi Üniversitesi Sosyal Bilimler Enstitüsü, İzmir.

Çelebi, Â. (2010). Meşâ'iru'ş-Şu'arâ. (Haz. F. Kılıç). İstanbul: İstanbul Araştırmaları Enstitüsü.

Çeltik, H. (2013). Rumeli Şairlerinin Şiir Dünyası. Ankara: Kurgan Edebiyat.

Dinçer, F. (2017). Rıfkı Melûl Meriç'in Yayımlanmamış Rubaileri. Tullis: The Journal of Turkic Language and Literature Surveys, II(2), 52-76.

Eren, H. (2001). Osmanlı Mirası Bir Medrese Örneği Gümülcine Medrese-i Hayriyesi. H. Y. Nuhoğlu (Ed.), Osmanlı Dünyasında Bilim ve Eğitim Milletlerarası Kongresi içinde (ss. 57-62). İstanbul: IRCICA.

Eren, H., \& Türe, İ. (2017). Mühimme Defterlerinde Gümülcine. İstanbul: BALMED.

Ergün, S. N. (1955). Bektâşî Şairleri ve Nefesleri. İstanbul: Maarif Kütüphanesi.

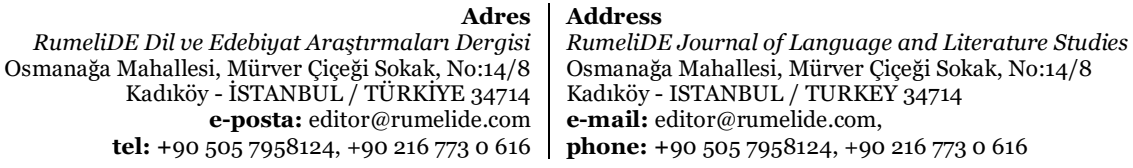


Ergün, S. N. (Tarihsiz). Türk Şairleri. İstanbul.

Erünsal, İ. E. (2004). XV-XVI. Asır Osmanlı Zendeka ve İlhad Tarihine Bir Katkı. Osmanlı Araştırmaları, 24, 127-157.

Esad, M. (1904). "Selânik Sâl Cedîd Meymenet Bedîd", Asır Gazetesi(868). (21 Mart 1904). Selanik. http://www.osmanlicagazeteler.org/incele.php?id=7203,\%2090o\&gor=Metin (Erişim Tarihi: 05.05.2021)

Esad, M. (1911). Reşâhat-ı Hikemiyye. İBB Atatürk Kitaplı̆̆ı, No. OE TK 2256, http://ataturkkitapligi.ibb.gov.tr/kutuphane3/kitablar/5400053000520005200051000950011 40011500069.pdf (Erişim Tarihi: 25.09.2020).

Esad, M. (1914). Cihâd-ı Ekber. İzmir: Ahenk Matbaası.

Esad, M. (1916). Hilâl-i Ahmer. İzmir: Keşişyan Matbaası.

Esad, M. (1922). Düşündüklerim, Dileklerim, Emeklerim. Manisa: İnkılâp Gazetesi Matbaası.

Esad, M. (1923). Halk Şiirleri. İstanbul: Teşbuat Matbaası.

Esad, M. (1924). Türk Dilinde Kinâyât. İzmir: Nazif Mustafa Matbaası.

Esad, M. (1924b). Verin Zavallılara. İzmir: Nafiz Mustafa Matbaası.

Esad, M. (1925). Türk Dilinde Darb-ı Meseller. İzmir: Ahenk Matbaası.

Esad, M. (1934). Bu Suya Sen de Eğil. İzmir: Suhûlet Matbaası.

Esad, M. (1945). Hadis-i Şerîf Tercümesi. İzmir: İstanbul Matbaası.

Esad, M. (1947). Sözlerin Özü Atalar Sözü. İzmir: Suhûlet Matbaası.

Esad, M. (1954). Rahmetli İmam Birgivî. İzmir: Hür Efe Matbaası.

Esad, M. E. (2018). Bağçe-i Safâ Endûz. (Haz. R. Oğraş). Ankara: Kültür ve Turizm Bakanlığı Yayınları. https://ekitap.ktb.gov.tr/TR-212024/esad-mehmed-efendi-bagce-i-safa-enduz.html (Erişim Tarihi: 01.03.2020)

Everdi, E., Kutlu, M., \& Kara, İ. (Dü). (1980). "Dürrî Gümülcinevî". Türk Dili ve Edebiyatı Ansiklopedisi, II, 400. İstanbul: Dergâh.

Eyice, S. (1993). "Çelebi Sultan Mehmed Camii". Türkiye Diyanet Vakfı İslam Ansiklopedisi, VIII, 262263. Istanbul: Türkiye Diyanet Vakfi.

Fatin, D. (2017). Hâtimetü'l-Eş'âr. (Haz. Ö. Çiftçi). Ankara: Kültür ve Turizm Bakanlığı Yayınları. https://ekitap.ktb.gov.tr/TR-195831/fatin-tezkiresi.html (Erişim Tarihi: 26.01.2020)

Gümüşatam, G. (2017). Erken Dönem Söz Derlemeleri İçin Kaynak Olarak Esad Efendi'nin Türk Dilinde Darb-1 Meseller Yayını. Uluslararası Sosyal Araştırmalar Dergisi, X(51), 68-81.

Gümüşoğlu, H. D. (2012). 15. Yüzyıl Bektâşîliğinde Sâdık Abdal Örneği. Alevîlik-Bektâşîlik Araştırmaları Dergisi(5), 1-25.

Gürbüz, İ. A. (Dü.). (2018). Mecmûa'atü'l-Letâif ve Sandukatu'l-Maârif. Ankara: Kültür ve Turizm Bakanlığı Yayınları. https://ekitap.ktb.gov.tr/TR-203807/mecmuatul-letaif-ve-sandukatulmaarif.html (Erişim Tarihi: 10.02.2020)

Hadîdî. (1991). Tevârih-i Âl-i Osman. (Haz. N. Öztürk). İstanbul: Marmara Üniversitesi.

Halaçoğlu, Y., \& Eren, H. (1992). "Batı Trakya". Türkiye Diyanet Vakfı İslam Ansiklopedisi, V, 144-147. İstanbul: Türkiye Diyanet Vakfı Yayınları.

İnal, İ. M. (2002). Son Asır Türk Şairleri. (Haz. İ. Baştuğ). Ankara: Atatürk Kültür Merkezi.

İnal, İ. M. (2013). Son Asır Türk Şairleri. (Haz. A. Celepoğlu). Ankara: Atatürk Kültür Merkezi.

İpekten, H., İsen, M., Toparlı, R., Okçu, N., \& Karabey, T. (1988). Tezkirelere Göre Divan Edebiyatı İsimler Sözlüğü. Ankara: Kültür ve Turizm Bakanlığı.

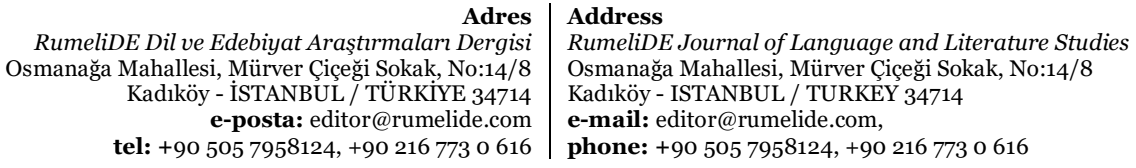


İsen, M. (1997). Ötelerden Bir Ses. Ankara: Akçă̆.

Kabîlî. (2018). Sultân-ı Hubâna Münâsib Eș'âr. (Haz. M. Gürbüz). Ankara: Kültür ve Turizm Bakanlığı Yayınları. https://ekitap.ktb.gov.tr/TR-208513/sulan-i-bana--munasib-esar.html (Erişim Tarihi: 10.02.2020)

Kalyon, A. (2011). Peşteli Hisâlî Metâli'u'n-Nezâ'ir (II. Cilt) İnceleme Metin. Doktora Tezi, Gazi Üniversitesi Sosyal Bilimler Enstitüsü, Ankara.

Kara, M. (2003). Rıfkı Melûl Meriç; Doğumunun 100. Yılında Melûl Bir Sanatçı. Uludağ Üniversitesi İlahiyat Fakültesi Dergisi, XII(1), 1-27.

Kaya, D. (2016). Ali Rıza Öge'nin Bektâşî Şairleri Antolojisinde Yer Alan Şairler. Alevilik Araştırmaları Dergisi, I(12), 211-297.

Kayabaşı, B. (1997). Kâf-zâde Fâizî'nin Zübdetü'l-Eş'âr'ı. Doktora Tezi, İnönü Üniversitesi Sosyal Bilimler Enstitüsü, Malatya.

Kiel, M. (1994). "Dimetoka". Türkiye Diyanet Vakfı İslam Ansiklopedisi, IX, 305-308. İstanbul: Türkiye Diyanet Vakfi.

Kiel, M. (1995). "Ferecik". Türkiye Diyanet Vakfı İslam Ansiklopedisi, XII, 371-373. İstanbul: Türkiye Diyanet Vakfi.

Kiel, M. (1996). "Gümülcine". Türkiye Diyanet Vakfı İslam Ansiklopedisi, XIV, 268-279. İstanbul: Türkiye Diyanet Vakfı.

Kiel, M. (2000). "İskeçe". Türkiye Diyanet Vakfı İslam Ansiklopedisi, XXII, 553-555. İstanbul: Türkiye Diyanet Vakfi.

Kılıç, A. (2012). Guzât Vakıflarına Bir Örnek: Gümülcine'de Gazi Evrenos Bey Vakfı. Balkanlarda Osmanlı Vakıfları ve Eserleri Uluslararası Sempozyumu içinde (ss. 259-276). Ankara: Vakıflar Genel Müdürlüğü.

Kılıç, İ. (2010). Gümülcineli Dürrî Divanı. Yüksek Lisans Tezi, Van Yüzüncü Yıl Üniversitesi Sosyal Bilimler Enstitüsü, Van.

Kınalızâde, H. Ç. (2017). Tezkiretü'ş-Şu'arâ. (Haz. A. S. Eyduran). Ankara: Kültür ve Turizm Bakanlığı Yayınlarl. https://ekitap.ktb.gov.tr/TR-194494/kinalizade-hasan-celebi-tezkiretus-s-uara.html (Erişim Tarihi: 10.02.2020)

Koca, Ş. (2005). Bektâşîlik ve Bektâşî Dergâhları. İstanbul: Cem Vakfı.

Koca, T. (1990). Bektâşî Nefesleri ve Şairleri. İstanbul: Maarif Kütüphanesi Matbaası.

Köksal, M. F. (2015). "Silahdâr Seyyid Mehmed Paşa". Türk Edebiyatı İsimler Sözlüğü. http://teis.yesevi.edu.tr/madde-detay/mehmed-silahdar-seyyid-mehmed-pasa (Erişim Tarihi: 26.09.2020)

Latîfî. (2000). Tezkiretü'ş-Şu'arâ ve Tabsıratü'n-Nuzamâ. (Haz. R. Canım). Ankara: Atatürk Kültür Merkezi Başkanlığı.

Mecdî, M. E. (1989). Hadâiku'ş-Şakâik, Şakâik-i Nu'mâniye ve Zeyilleri. (Haz. A. Özcan). İstanbul: Çağrı.

Meriç, R. M. (1928). İnkıraz. Ankara: Hakimiyet-i Milliye Matbaası.

Meriç, R. M. (1937). Türk Tezyinî Sanatları. İstanbul: Güzel Sanatlar Akademisi Neşriyatı.

Meriç, R. M. (1951). Rubaiyyât-ı Melûl. (Haz. H. Z. Ülken). İstanbul: Millî Mecmua.

Meriç, R. M. (1953). Türk Nakış Sanatı Tarihi I. Cilt: Vesikalar. Ankara: Ankara Üniversitesi İlahiyat Fakültesi Türk Ve İslam Sanatları Enstitüsü.

Meriç, R. M. (1954). Türk Cilt Sanatı Tarihi Araştırmaları. Ankara: Ankara Üniversitesi İlahiyat Fakültesi Türk ve İslam Sanatları Enstitüsü.

Meriç, R. M. (1965). Mimar Sinan Hayatı, Eseri I. Ankara: Türk Tarih Kurumu.

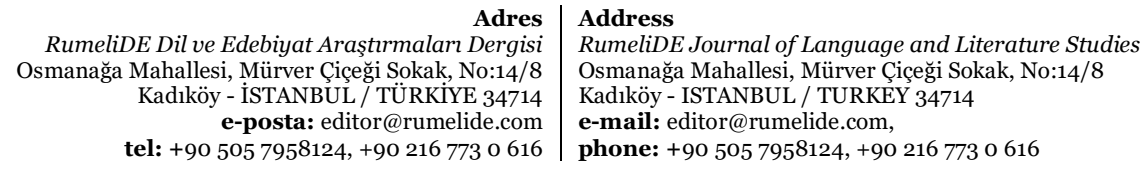


Morkoç, E. (2003). Eğirdirli Hacı Kemal'in Câmi'u'n-Nezâir'i. Doktora Tezi, Ege Üniversitesi Sosyal Bilimler Enstitüsü, İzmir.

Nazmî, E. (2017). Mecma'u'n-Nezâir. (Haz. M. F. Köksal). Ankara: Kültür ve Turizm Bakanlı̆̆ı Yayınları. https://ekitap.ktb.gov.tr/TR-195954/mecmaun-nezair-edirneli-nazmi.html (Erişim Tarihi: 10.01.2020)

Ocak, A. Y. (1992). "Balım Sultan". Türkiye Diyanet Vakfı İslam Ansiklopedisi, V, 17-18. İstanbul: Türkiye Diyanet Vakfı.

Özcan, A. (1993). "Çarhacı". Türkiye Diyanet Vakfi İslam Ansiklopedisi, VIII, 229-23o. İstanbul: Türkiye Diyanet Vakfi.

Özmen, İ. (1998). Alevî-Bektâşî Şiirleri Antolojisi. Ankara: Kültür ve Turizm Bakanlığı.

Öztürk, N. (1989). Ferecik’in Süleyman Paşa Tarafından Fethine Dair. Türklük Araştırmaları Dergisi, 1988(2), 135-145.

Parlak, C. (2013). XV. ve XVI. Yüzylllarda Gümülcine Şehrinin İktisadî Durumu Üzerine Tespitler. Trakya Üniversitesi Edebiyat Fakültesi Dergisi, III(6), 85-120.

Parlak, C. (2018). Defterdâr Ahmed Efendi Vakfinın Gümülcine'deki Mülkleri. C. Eraslan, C. Bayram, \& N. Erdem (Ed.), Balkanlarda Türk Kültürü: Batı Trakya Uluslararası Sempozyumu içinde (ss. 23-53). İstanbul: Türk Ocağı.

Pervâne, B. (2017). Mecmuatü'n-Nezâir. (Haz. K. A. Giynaş). Ankara: Kültür ve Turizm Bakanlığı Yayınları. https://ekitap.ktb.gov.tr/TR-194492/pervane-bey-mecmuasi.html (Erişim Tarihi: 10.02.2020)

Rif'at, İ. (2019). Âyine-i Zafer. (Haz. H. Koç, B. Kesik, \& M. Büyükada). Ankara: Akçağ.

Riyâzî, M. E. (2017). Riyâzü'ş-Şu'arâ. (Haz. N. Açıkgöz). Ankara: Kültür ve Turizm Bakanlı̆̆ı Yayınları. https://ekitap.ktb.gov.tr/TR-191371/riyazi-riyazus-suaratezkiretus-suara.html (Erişim Tarihi: 18.06.2020)

Sami, Ş. (1316/1898). Kâmusu'l-A'lâm. İstanbul: Mihran Matbaası.

Sehî, B. (1998). Heşt Behişt. (Haz. M. İsen). Ankara: Akçă̆.

Sezgin, İ. (2015). Osmanlıların Rumeli'ye Geçişi ve İlk Fetihler. Yeni Türkiye(69), 3948-3953.

Sıdkî, M. (1319/1902). Leylâk. İstanbul: Asır Matbaa ve Kütüphanesi.

Sıdkî, M. (1327/1911). Hüsn-i Melûl. Edirne: Yako Levi Matbaası.

Soileu, M. (2014). Sâdık Abdal Divan'ında Bektâşîliğin Teşekkülü. S. Akkuş, H. Şahin, M. M. Dündar, H. Kartaloğlu, \& F. Doğruyol (Ed.), Uluslararası Alevî-Bektâşî Klasikleri Sempozyumu içinde (ss. 7988). Sakarya: Sakarya Üniversitesi.

Süreyya, M. (1996). Sicill-i Osmanî. (Haz. N. Akbayar). İstanbul: Tarih Vakfi Yurt.

Şahin, H. (2009). "Seyyid Ali Sultan". Türkiye Diyanet Vakfı İslam Ansiklopedisi, XXXVII, 48-50. İstanbul: Türkiye Diyanet Vakf.

Tahir, M. (1972). Osmanlı Müellifleri. (Haz. A. F. Yavuz, \& İ. Özen). İstanbul: Meral.

Tan, B. (2014). "Sâdık Abdal". Türk Edebiyatı İsimler Sözlüğü. http://teis.yesevi.edu.tr/maddeetay/sadik-abdal (Erişim Tarihi: 23.09.2020)

Tanman, M. B. (1989). "Akbıyık Mescidi ve Tekkesi". Türkiye Diyanet Vakfı İslam Ansiklopedisi, II, 222223. İstanbul: Türkiye Diyanet Vakfi.

Tanyldız, A. (2014). "Visâlî". Türk Edebiyatı İsimler Sözlüğü. http://teis.yesevi.edu.tr/maddedetay/visali-visali-celebi-dimetokali (Erişim Tarihi: 28.09.2020)

TBMM Yasama Organı Üyelerinin Tercüme-i Halleri Arama Motoru. https://www.tbmm.gov.tr/develop/owa/milletvekillerimizeski.sonuc?adi=\&soyadi=\&il=\&mecli $\mathrm{s}=1-1 \&$ kelime (Erişim Tarihi: 25.09.2020)

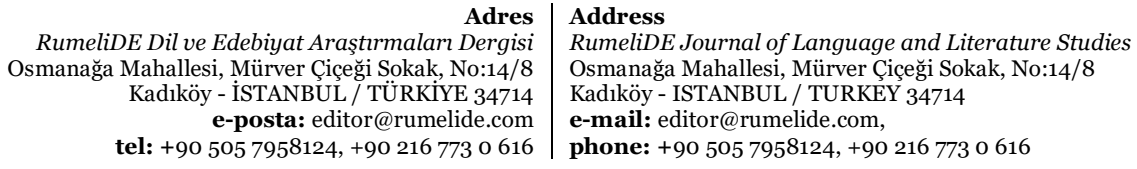


Tevfik, M. (2017). Kâfile-i Şu'arâ. (Haz. F. S. Oğuz, H. Koncu, \& M. Çakır). Ankara: Kültür ve Turizm Bakanlığı Yayınları. https://ekitap.ktb.gov.tr/TR-196469/mehmed-tevfik-kafile-i-su39ara.html (Erişim Tarihi: 23.06.2020)

Tevfikoğlu, M. (1979). Ölümünün Onbeşinci Yllında Rıfkı Melûl Meriç'in Şiirleri. Türk Kültürü, XVII(196), 15-26.

Tevfikoğlu, M. (1986). Rıfkı Melûl Meriç. Ankara: Kültür ve Turizm Bakanlığı.

Timurtaş, F. K. (1964). Rıfkı Melûl Meriç. Türk Kültürü, II(17), 51.

Tıraş, Y. C., \& Ertürk, H. İ. (2017). Gümülcineli Esad Efendi ve Türk Dilinde Kinâyât Adlı Eseri. Littera Turca Journal of Turkish Language and Literature, III(2), 235-258.

Tuğlacı, P. (1985). Osmanlı Şehirleri. İstanbul: Milliyet.

Tuman, M. N. (2001). Tuhfe-i Nâilî. (Haz. C. Kurnaz, \& M. Tatcı). Ankara: Bizim Büro.

Tunalı, A. C. (2007). Kurtuluş Savaşında Esat Efendi (İleri). Tarih Araştırmaları Dergisi, XXVI(41), 81100.

Ülken, H. Z. (1964). Rıfkı Melûl Meriç. Ankara Üniversitesi İlahiyat Fakültesi Dergisi, XII, 135-137.

Yalçın, M. (Dü.). (2010). Tanzimattan Bugüne Edebiyatçılar Ansiklopedisi. İstanbul: Yapı Kredi.

Yazar, İ. (2007). Dürrî'nin Şehrengizinden Gümülcine'ye Bakış. Turkish Studies-International Periodical For The Languages, Literature and History of Turkish or Turkic, II(2), 770-789.

Yazar, İ. (2009). Dürrî'nin Moton Şehrengizi. ERDEM Atatürk Kültür Merkezi Dergisi(55), 175-190.

Yıldız, T. (2015). "Pâkî". Türk Edebiyatı İsimler Sözlüğü. http://teis.yesevi.edu.tr/madde-detay/paki (Erişim Tarihi: 23.09.2020)

RumeliDE Dil ve Edebiyat Araştırmaları Dergisi Osmanağa Mahallesi, Mürver Çiçeği Sokak, No:14/8 Kadıköy - İSTANBUL / TÜRKIYE 34714 e-posta: editor@rumelide.com tel: +90 $5057958124,+902167730616$
Address

RumeliDE Journal of Language and Literature Studies Osmanağa Mahallesi, Mürver Çiçeği Sokak, No:14/8

Kadıköy - ISTANBUL / TURKEY 34714

e-mail: editor@rumelide.com,

phone: +90 $5057958124,+902167730616$ 